\title{
1948 年福井地震の強震動
}

\section{—ハイブリッド法による広周期帯域強震動の再現——}

\author{
京都大学防災研究所* 入 倉 孝次郎 \\ 京都大学原子炉実験所** 釜 江 克 宏
}

\section{Strong Ground Motions during the 1948 Fukui Earthquake}

\author{
-Estimation of Broad-band Ground Motion Using \\ a Hybrid Simulation Technique-
}

\author{
Kojiro IRIKURA \\ Disaster Prevention Research Institute, Kyoto University, Gokasho, Uji, \\ Kyoto 611-0011, Japan \\ Katsuhiro KamaE \\ Research Reactor Institute, Kyoto University, Kumatori, Sennan, \\ Osaka 590-0494, Japan
}

(Received March 30, 1999; Accepted June 7, 1999)

\begin{abstract}
We simulate strong ground motions during the 1948 Fukui earthquake with the JMA magnitude 7.1 based on a heterogeneous source model and the hybrid simulation technique. So far there are no existing source models available for simulating strong ground motions from the 1948 Fukui earthquake. Most of the source models have been assumed to have uniform slip distribution on rectangular fault plane. Such models could generate ground motions only available longer than several seconds, underestimating shorter period motions $(<1 \mathrm{sec})$ of engineering interest. The objective of this paper is to construct a heterogeneous source model for simulating strong ground motions in a broad period band during the 1948 Fukui earthquake. We assume two source models to examine: Model 1 is a reverse fault model determined from the analysis of geodetic data by Yosнioк A (1974) and Model 2 is a normal fault model from strong motion displacement data by КıкUсHI et al. (1999). Heterogeneous slip distribution on fault plane is estimated based on the self-similar scaling relationships of seismic moment versus asperity areas and slips by Somerville et al. (1999). Then we obtained the standardized source model consisting of two asperities to have the average characteristics of asperities for the seismic moment of the Fukui earthquake. Relative locations and rupture times of the asperities on the fault plane are determined following the source model by KiKUCHI et al. (1999). The maximum asperity corresponding to the second event in their model has an area of $12 \times 12 \mathrm{~km}^{2}$ and slip of 1.7 $\mathrm{m}$ and is located under the most heavily damaged area along the buried fault, known as the Fukui earthquake fault. The smaller asperity corresponding to the first event is located north of the maximum asperity. Rupture was initiated at the northern edge of the smaller asperity, propagated toward south, then broke to start the maximum asperity 7 seconds after the initial rupture. Large ground motions from both models, Model 1 and 2, are spread over the Fukui basin, although peak velocity distributions are rather different between the two models. Areas over $30 \%$ collapse ratio during the Fukui earthquake correspond to those with peak velocity over $60 \mathrm{~cm} / \mathrm{s}$ for Model 1 and over $80 \mathrm{~cm} / \mathrm{s}$ for Model 2. The level of the peak velocity in the areas with more than $30 \%$ collapse ratio are estimated to be over $80 \mathrm{~cm} / \mathrm{s}$ connected with both results by Moror et al. (1998) and Miу акоsнi and Hayashi (1998). Pseudo velocity response spectra in the center of the Fukui basin for
\end{abstract}


Model 2 have almost the same level of the observed ones at Takatori (TKT) and the simulated ones at Fukuike (FKI) within the damage belt during the 1995 Hyogo-ken Nanbu earthquake. We conclude that the damage distribution during the Fukui earthquake is well explained by strong ground motions simulated for Model 2 combined with the normal fault model by KıкUCHI et al. (1999) and a standardized heterogeneous source model developed by Somerville et al. (1999).

Key words: the 1948 Fukui earthquake, strong ground motion, heterogeneous source model, asperity, collapse ratio.

§1. はじめに

50 年前に福井市およびその周辺地域に大災害をもた らした 1948 年福井地震は福井市近郊を走る活断層に起 因する内陸地震で，いわゆる都市直下地震の 1 つであっ た.この地震の規模は気象庁マグニチュード $\left(M_{\mathrm{J}}\right) 7.1$ で，兵庫県南部地震 $\left(M_{\mathrm{J}} 7.2\right)$ とほぼ同じであった。この 地震は戦後の混乱期に起こったにもかかわらず，全国の 地震学, 地震工学の研究者により, 発生直後から余震観 測, 断層・地盤調查, 被害調査がなされ, 詳細な報告書 が出版されている [北陸震災特別委員会 (1951)]．この 時はじめて高感度の微小地震観測がなされ貴重な余震記 録が得られたり [ASADA and SUZUKI (1949)], 被害地で の地震波探査による地盤調査がなされる [吉川 (1950)]
など地震学的にあ記念碑的地震の 1 つである.

最近福井県が出版した「よみがえる福井震災」, [谷口 (1998)］は生々しい被害の実態および困難な中の調查の 様子を教えてくれる，GHQによる緊急調查 (Fig. 1) に 示されるように，震源近傍域では家屋倒壊率 $90 \%$ 以上 の地域が 2 つに別れて存在し，1つは盆地中心部の長さ 約 $15 \mathrm{~km}$ 幅約 $8 \mathrm{~km}$ の広い領域, あう 1 つはその北側 の海岸部沿いに長さ $5 \mathrm{~km}$ と幅 $2 \mathrm{~km}$ の小さな領域であ る。家屋全壊率が $50 \%$ 以上の地域は長さ約 $30 \mathrm{~km}$ 幅約 $12 \mathrm{~km}$ に広がっている. 死亡率の分布 (Fig. 1 右図) が 家屋全壊率に対応していることがよく分かる。この被害 率のマップ自体は必ずしも正確ではないが，被害の広が りは 1995 年兵庫県南部地震に比べてはるかに大きく，

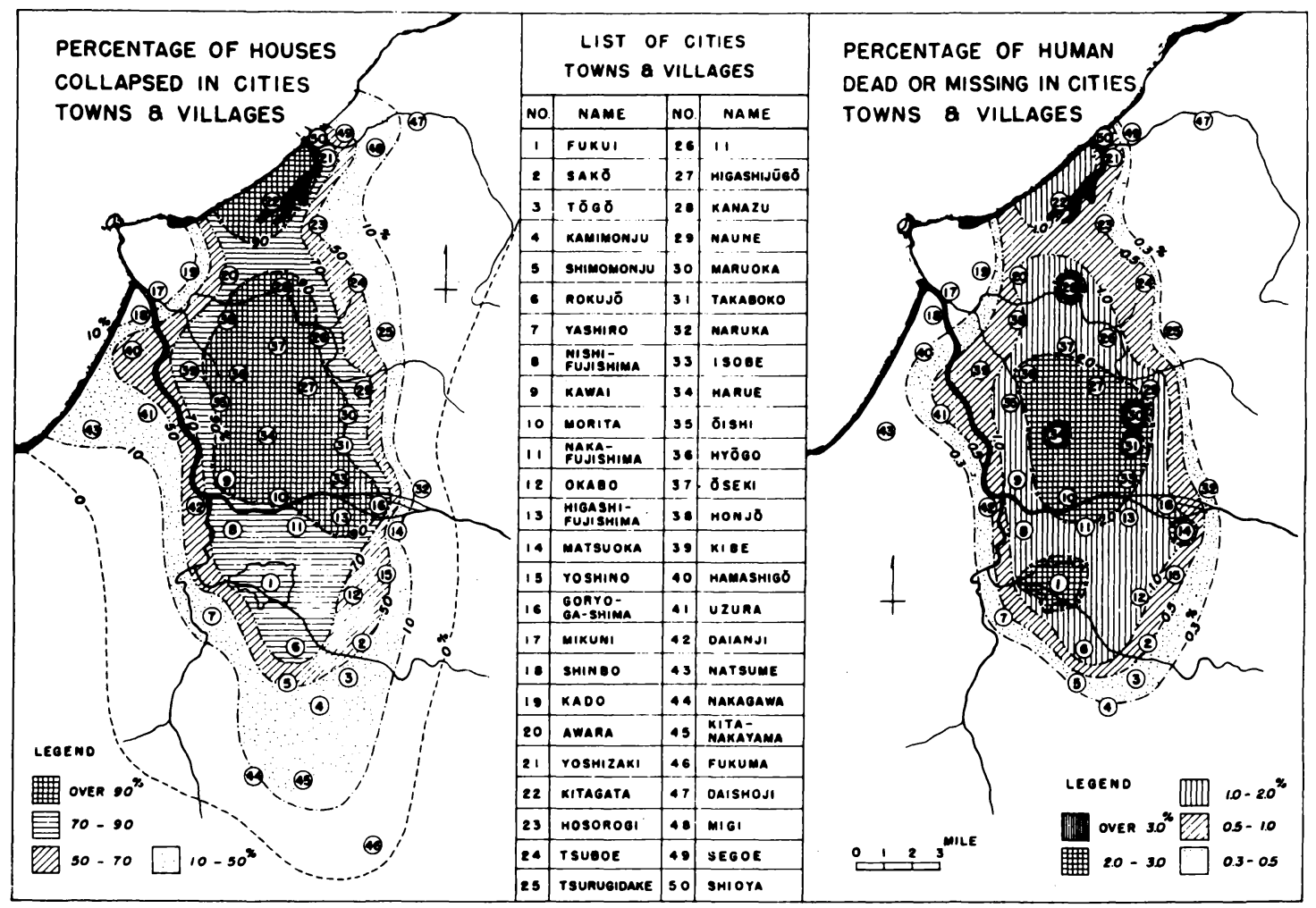

Fig. 1. Map showing the percentage of houses collapsed (left) and human dead including missing [GHQ's Report]. 
被害の元となった破壊力のある強震動が広い領域に生じ ていたのではないかと想像される.

1995 年兵庫県南部地震では日本ではじめて大被害が 生じた地域で強震動が記録された。 それにより断層破壊 の前方伝播による指向性効果により生成される長周期パ ルスの存在と盆地端部効果による増幅が大きな衝撃的な 震動を生じ, 構造物を破壊に至らしめたことがわかって きた [例えば, IRIKURA et al. (1996); KAWASE (1996)]. 福井地震のとき被害を引き起こした強震動がどのような あのであったかに関する研究は殆どなされていない. そ の理由は震源域近傍で地震動が全く記録されていないこ とにある. 日本の多くの都市が福井市同様に活断層に囲 まれていることを考えると福井地震の強震動の検討は重 要である.

先にあげた調查委員会のリポートでは震源近傍域での 倒壊した記念碑や橋げたなどから最大加速度が $0.6 G$ 以 上あったと推定している. 災害地での地震動周期は, 根 拠は明確でないが, 約 1.5 秒と推定している.この周期 は兵庫県南部地震のパルスの周期とほぼ同じである. 地 表断層は現れなかったが, 地震直後ほぼ南北方向の線上 にエシュロン状の地割れが見られたことから伏在断層の 存在が推定されている. KANAMORI (1973) は余震分布, 断層地殻変動データ, および近距離での強震変位記録を 用いて単純な長方形の震源断層モデルを推定している.
その後も吉岡 (1974) と長谷川 (1986) らにより，水平お よび上下の地款変動データなよ゙の詳細な解析により, 震 源断層モデルの再検討がなされている. しかしながら， これらのモデルはいずれす極めて長周期の波動或いは静 的な変動に対しては有効であっても震源域の強震動の評 価にそのまま適用するのは困難である.

将来発生する地震に対する強震動を予測するには, 断 層震源域のみならず，地震モーメントや断層すべりの不 均質分布などの震源のモデル化が必要とされる. 我々は 米国の研究者と共同で，強震動記録や遠地地震記録を用 いた同一手法でなされた震源インバージョン結果を 集め, その統計的解析に基いた震源モデルの経験的モ デル化について研究を行ってきた [SOMERVILLE et al. (1999)]. 本研究ではこの経験的モデル化の手法を福井地 震に適用して断層破壊を想定した強震動の評価を試み， その有効性を震源近傍域の被害分布と比較することによ り検証する.

\section{§2. 手法}

\section{1 ハイブリッド法による強震動評価}

最近数值シミュレーション手法の発達により, 震源断 層モデルを仮定し，震源域から対象地域に到る地下構造 を考虑して，震源で生成され地層中を伝播する地震動を 理論的に求める方法が開発されてきた．この方法は, 強

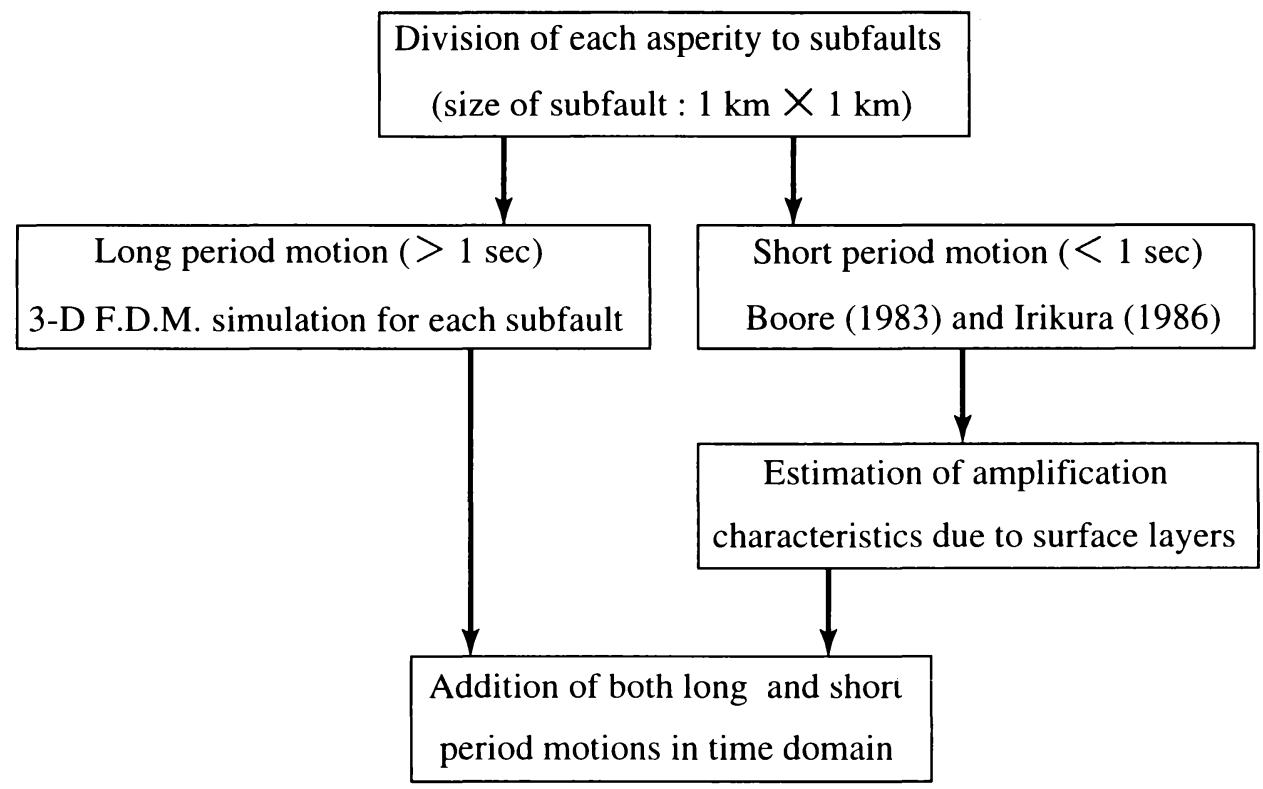

Fig. 2. Flow chart of simulation procedure of strong ground motions using a hybrid scheme. The long period motions for the hypothetical large-earthquake are simulated using the 3-D Finite Difference Method considering the 3-D structure. The short period motions for the large earthquake are calculated following the empirical Green's function method by IRIKURA (1986) in which small event motions calculated with the stochastic simulation method by Boore (1983) are summed. 
震動記録を用いて波形インバージョンにより断層破壊過 程推定のために利用され，断層面上のすべり分布が精度 よく求められるようになった。しかしながら，この場合 理論波形の計算には簡単化された平行多層構造が仮定さ れ，解析に有効な地震記録の周期範囲は 1 秒以上の長周 期帯域のみである. 構造物被害には一般に 0.1 10 秒の 広い周期帯域の強震動が関係していると考えられる。 そ のため, 震源インバージョンに用いられる地震動推定方 法をそのまま強震動の予測に適用することはできない.

現実的な強震動の推定でこれまでもっとも成功してい る手法は，想定する断首近傍に発生した小地震の記録を 用いて大地震の強震動を推定する，いわゆる経験的グ リーン関数法 [例えば, IRIKURA (1986)] と考えられる. しかしながら，この方法も，一般には適切な小地震記録 がない場合が多くいつであ使えるわけではない.

最近震源断層モデルと震源域を含む 3 次元構造が与 えられたとき, 3 次元有限差分法 (3D-F. D. M.) を用いて 1 秒より長周期の地震動の計算が可能になってきた [例 えば, Graves (1996), Pitarka et al.(1998)].しかしな がら, 周期 1 秒より短周期の地震動を理論的に計算する に十分な詳細地下構造を広域にわたって決定するのはい まだ困難であり,さらにその数值シミュレーション手法 あ確立しているとはいえない。

そこで本研究では Fig. 2 に示されるハイブリッド法 を用いて震源近傍の強震動合成を試みる. 長周期（1 秒 以上）は，3D-F.D. M. を用い，対象とする大地震の断層 面を適当な小断層に分割し，各小断首にベル型関数であ らわされるすべり速度時間関数を想定し， 3 次元の地下 構造を考虑して直接的に大地震の地震動のシミュレー ションを行う.一方, 短周期 (1 秒以下) については, は じめに小地震からの地震動を, 震源特性として $\omega^{2}$ モデ ルを仮定し, 伝播経路特性とサイト特性を考慮して確率 的手法でシミュレーションを行い [BOORE (1983)], 次 に, 経験的グリーン関数法と同様の手続きで小地震記録 を足しあわせて断層面全体からの地震動合成を行う，い わゆる統計的波形合成法 [釜江・他 (1991)] を用いる. 長周期地震動と短周期地震動は, 両者の震源関数の足し

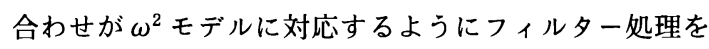
した後，時間領域で足しあわされて，広周期帯域の強震 動が合成される.

KAMAE et al. (1998) のハイブリッド・グリーン関数 法は, 経験的グリーン関数法に準じて本震の断層面内に 発生する数個の小地震に対応する地震動の計算を行い, 本震断層面からサイトまでのグリーン関数として代用さ せている. 本研究の方法は長周期地震動については厳密 に理論的方法で計算を行っている点が彼らの方法と異な
る. 断層近傍の地震動は断首面上のすべり方向による放 射特性の影響が大きいので, 本手法はより精度の高い強 震動評価手法と考えられる。

\section{2 强震動予測のための震源のモテル化}

活断層に起因する地震を想定して強震動予測を行うに は，はじめに震源断層のモデル化が必要となる．これま では, 地質・地形・地球物理学的調查に基づき, 断層走 向や傾斜角などの断層面の幾何学形状と断層の長さ $(L)$ から地震規模をあらわすマグニチュードが推定され, 地 震マグニチュードを基に経験的関係式にしたがって断首 すべり，ライズタイムなどの震源パラメターを推定する という方法が多く行われてきた。しかし，断首パラメ ター・ハンドブックに掲載されたパラメターは地款変動 や津波のデー夕解析により決められたものが多い．この ような方法による震源モデルは数秒から数十秒の長周期 の地震動には有効と思われるが，10 秒から 0.1 秒の短 周期帯域の卓越する強震動推定は一般に困難と考えられ る [例えば, KAMAe and IrIKURA (1998)].

最近 20 年ほどの間に, マグニチュード 6 以上の内陸 地震に対して線形波形インバージョンを用いて信頼性の ある断首すべりが少しづつ明らかになってきた。これら の結果は断層すべりは決して断層面上に一様ではなく不 均質であることを示すすのであった. SoMERVILLE et al. (1999) はこれらの震源モデルの体系的な特性を見出す ための統計的解析をおこなった.

解析により求められた全断首面積 $S$, 最大アスペリ ティーの面積 $S m$, およびアスペリティーの面積の総和 $S a$, と地震モーメントの関係は

$$
\begin{aligned}
& S\left(\mathrm{~km}^{2}\right)=2.23 \times 10^{-15} \times M o^{2 / 3}(\text { dy ne } \cdot \mathrm{cm}) \\
& S m\left(\mathrm{~km}^{2}\right)=3.64 \times 10^{-16} \times M o^{2 / 3}(\text { dyne } \cdot \mathrm{cm}) \\
& S a\left(\mathrm{~km}^{2}\right)=5.00 \times 10^{-16} \times M o^{2 / 3}(\text { dyne } \cdot \mathrm{cm})
\end{aligned}
$$

のようにあらわされる. 全断層面積 $S$ とアスペリティー の面積 $S m$ と $S a$ とも地震モーメントMoに対して両対 数座標上で傾きは $2 / 3$ となっている. このことは, 全断 層面積, 最大アスペリティーの面積, およびアスペリ ティーの面積の総和が地震モーメントをパラメターとし て自己相似型のモデルを仮定していることに対応する.

震源インバージョンで得られた断層上の平均すべり継 続時間 $\operatorname{Tr}$ と地震モーメントの関係は傾きが $1 / 3$ の直線 にのっている.

$$
\operatorname{Tr}(\mathrm{s})=2.03 \times 10^{-9} \times M o^{1 / 3}(\text { dyne } \cdot \mathrm{cm})
$$

このことはすべり速度（Tr に対するすべり量 $D$ の比） が平均的にはほぼ一定であることに対応する。しかしな がら, 震源インバージョン解析を行うとき一般に 1 秒よ りも短周期を遮断フィルターで落とした長周期成分のみ の記録を用いるため, 結果として信頼性のあるライズ夕 
イムは 1 秒よりあ長周期に限られることに注意を要す る.

ここで定義されたアスペリティの領域やすべり量が強 震動評価に有効かどうかは，認定したアスペリティーの 分布を想定してフォーワード・モデリングで強震動を合 成して観測と比較することにより吟味する必要がある [例えば, KAMAE and IRIKURA (1998)].上のようなアス ペリティーの定義の有効性の検証は SOMERVILLE et al. (1999) ではなされていない. その検証も本研究の目的の 1 つである.

\section{§ 3. 福井地震の震源断層モデルの設定}

\section{1 福井地震の断層モテルのまとめ}

日本の地震断層パラメター・ハンドブック [佐藤 (1989)］によると福井地震の震源モデルについて前述の KANAMORI (1973), 吉岡 (1974) および長谷川 (1986)に よるものが載せられている. KANAMORI (1973) は地割 れ線分布と余震域の広がりから震源断層を, $L=30 \mathrm{~km}$, $W=13 \mathrm{~km}$ と推定し, 三角点の水平変動データと震源 から約 $155 \mathrm{~km}$ 離れた京大阿武山地震観測所での佐々 式強震計による変位記録を用いて, 震源メカニズムは 垂直左横ずれ断層, 地震モーメント $(M o)$ は $3.3 \times 10^{26}$ dyne $\cdot \mathrm{cm}$ と推定している. 震源は 2 つのサブイベント からなる多重震源で， はじめのイベントの約 9 秒後に 4 倍の大きさの第 2 イベントが生じたとしている. 主たる 被害はこの第 2 イベントによると考えられる.しかし, 均質等方の完全無限媒質を仮定した単純な長方形震源断 層モデルを用いた計算のため波形の一致は必ずしあよく ない. その後, 吉岡 (1974) は余震分布が地割れ線の東側 に偏在すること, 上下の地殻変動が東側隆起を示すこ と，等から，垂直断層面でなく傾斜角約 $80^{\circ}$ の逆断層を 仮定して, 理論地款変動と観測データの比較から断層モ デルの最適解としてすべり角 $26^{\circ}$ で地震モーメント 3.2 $\times 10^{26} \mathrm{dyne} \cdot \mathrm{cm}$ と推定した. 長谷川 (1986) は断層面を 8 枚の小断層に分けそれぞれ断層パラメターを未知数と して地殼変動データの非線形インバージョン解析を行っ た. 彼のモデルは仮定された断層面積が小さいため地震 モーメント $\left(M o=1.8 \times 10^{26} \mathrm{dyne} \cdot \mathrm{cm}\right)$ がやや小さいが, 平均的な傾斜角やすべり角は吉岡の結果とほぼ一致する 結果を得ている.

1998 年秋の地震学会で福井地震 50 周年を記念して 行われた特別セッションでは, 震源モデルの再検討結果 が発表された，菊地・他 (1999) は, 阿武山に加えて, 豊 岡, 亀山, 岐阜の低倍率変位計の記録を用いて波形イン バージョンを行い, 走向 $170^{\circ}$, 傾斜角 $70^{\circ}$, すべり角一 $10^{\circ}$, 地震モーメント $2.0 \times 10^{19} \mathrm{Nm}$ の解を得ている.こ
れは西落ちの正断層成分を持つもので先に述べた吉岡や 長谷川の結果とは異なっている. 彼らの解は, 主要なず

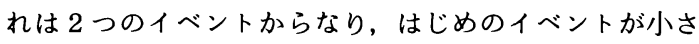
く， 2 番目のイベントが最大のずれを生じたとし，2つ のイベントのモーメント比が約 $1: 3$, 破壊はおおむね北 から南へ伝播したと報告した. 䉆谷 (1999) は, 水平およ び上下地殻変動データのインバージョン解析を地割れ分 布に対応する福井地震断層 (長さ約 $30 \mathrm{~km}$ ) だけが動い たと仮定したとき地震モーメントが $2.37 \times 10^{19} \mathrm{Nm}$, 左 横ずれが卓越して最大すべりは $6 \mathrm{~m}$ と推定した. 彼は この主断層から $3 \mathrm{~km}$ 離れて平行する副断層（長さ約 $7 \mathrm{~km}$ ) あ動いた可能性を指摘し, その場合地震モーメン トは $2.89 \times 10^{19} \mathrm{Nm}$ となるとしている.

\section{2 不均質断層モデル（アスペリティ・モデル）の構 勧}

1948 年福井地震は伏在断層のため地表踏査では地表 断層は確認されていない. 地表の割れ目の分布からのみ ではおそらく震源域は過小評価となる. KANAMORI

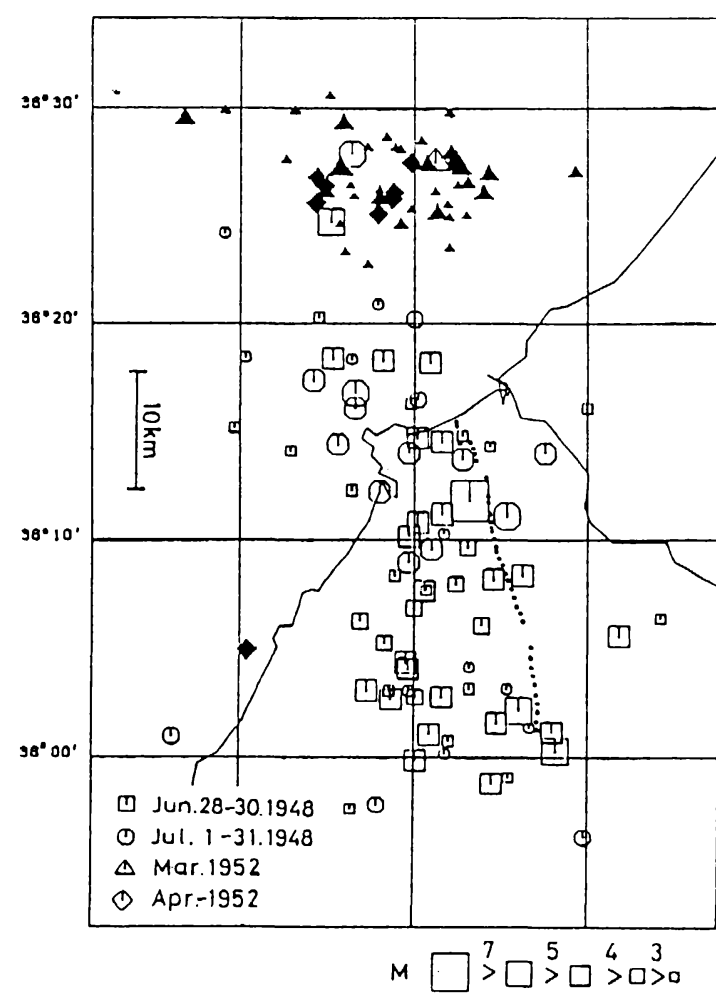

Fig. 3. Aftershocks of the 1948 Fukui earthquake ( $\square$ and $\bigcirc$ ) by Hamada (1987). The dotted lines indicate surface fissures appeared just after the 1948 Fukui earthquake. Aftershocks of the Daishojioki earthquake $(\boldsymbol{\Delta}$ and $\boldsymbol{\Delta}$ ) are also plotted on the map. 
(1973) は余震分布から震源断層の長さを陸域に約 $30 \mathrm{~km}$ としているが, 浜田 (1987) による震源の再決定 (Fig. 3) では, 余震域は内陸部だけにとどまらず, 本震直 後から北の沖合いにも発生しており，本震の破壊域は $30 \mathrm{~km}$ よりも長かった可能性を示唆している. 近距離 の地震記録を解析した KANAMORI (1973) あ菊地・他

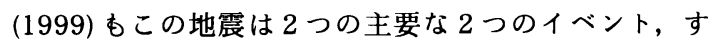
なわちアスペリティー，からなる多重震源モデルで説明 されるとし，各イベントを等価な点震源と考えてそれぞ れの地震モーメントを推定している．前章で述べたよう に震源近傍域の強震動を推定するには, 断層の長さ, 幅, 平均すべり量などの巨視的パラメターのみならず, アス ペリティの大きさやその分布形状などの震源のモデル化 が必要とされる. しかしながら，この地震についてこれ まで報告された観測データからこれらの震源パラメター
を全て決めることは困難である. 本研究では, 震源をあ らわす基本的パラメターである地震モーメントと震源断 層面の幾何形状はこれまでの震源断層モデルの研究結果 を参考にして設定する. 震源断層面積や断層面内のすべ り分布はこれまでの震源インバージョンの統計解析で得 られた平均的な震源特性を想定して強震動の評価を試み る. 震源の不均質性を示すアスペリティーの面積やそこ でのすべり量は SOMERVILLE et al. (1999) に基いて地震 モーメントに関する自己相似を仮定した関係式から推定 する. しかしながら，断層面内でのアスペリティーの位 置は彼らの結果から直接的には決められず断層の幾何形 状や地球物理学的環境から推定する必要がある.

この地震の震源断層メカニズムに関しては大きく分け ると 2 つ異なったモデルが報告されている．1つは地 壳変動データを基にした吉岡 (1974)による東落ちの逆

Table 1. Source parameters for simulating strong ground motions during the 1948 Fukui earthquake. The parameters correspond to the main causative fault and two asperities in the fault plane in Fig. 4 and the inhomogeneous source model with two asperities in Fig. 5. The references for estimating the parameters are shown in the right-most column (comments).

\begin{tabular}{|c|c|c|}
\hline Parameters & Estimates & Comments \\
\hline \multirow[t]{2}{*}{ Strike $\cdot$ Dip $\cdot$ Rake } & (1) $345^{\circ} \cdot 80^{\circ} \cdot 26^{\circ}$ & Yoshioka (1974) \\
\hline & (2) $170^{\circ} \cdot 70^{\circ} \cdot-10^{\circ}$ & Kikuchi et al. (1999) \\
\hline Seismic Moment $\left(\mathbf{M}_{0}\right)$ & $2.6 \times 10^{19} \quad(\mathrm{~N} * \mathrm{~m})$ & $* 1$ \\
\hline Number of Asperities & 2 & Kikuchi et al.(1998) \\
\hline Rupture Area (S) & $908 \mathrm{~km}^{2}$ & Somerville et al. (1999) \\
\hline Combined Area of Asperities $\left(S_{a}\right)$ & $204 \mathrm{~km}^{2}$ & Somerville et al. (1999) \\
\hline $\begin{array}{l}\text { Area of Largest Asperity }\left(\mathrm{S}_{\mathrm{a} 2}\right) \\
\text { (No.2 Asperity) }\end{array}$ & $\begin{array}{c}148 \mathrm{~km}^{2} \\
(12 \mathrm{~km} \times 12 \mathrm{~km})\end{array}$ & Somerville et al. (1999) \\
\hline $\begin{array}{l}\text { Area of Another Asperity }\left(\mathrm{S}_{\mathrm{a} 1}\right) \\
\text { (No.1 Asperity) }\end{array}$ & $\begin{array}{c}56 \mathrm{~km}^{2} \\
(7 \mathrm{~km} \times 8 \mathrm{~km})\end{array}$ & $\mathrm{S}_{\mathrm{a} 1}=\mathrm{Sa}-\mathrm{S}_{\mathrm{a} 2}$ \\
\hline Seismic Moment of No.2 Asperity $\left(\mathrm{M}_{02}\right)$ & $8.3 \times 10^{18} \quad\left(\mathrm{~N}^{*} \mathrm{~m}\right)$ & $\mathrm{M}_{02}=\mathrm{M}_{0} \times \mathrm{S}_{\mathrm{a2}} / \mathrm{S} \times 2.0$ \\
\hline Seismic Moment of No.1 Asperity $\left(\mathrm{M}_{01}\right)$ & $3.2 \times 10^{18} \quad\left(\mathrm{~N}^{*} \mathrm{~m}\right)$ & $\mathbf{M}_{01}=\mathbf{M}_{0} \times \mathrm{S}_{\mathrm{a} 1} / \mathrm{S} \times 2.0$ \\
\hline Stress Drop of No.2 Asperity & 113 (bars) & $\Delta \sigma=7 / 16 \times M_{0 x} / r^{3}$ \\
\hline Stress Drop of No.1 Asperity & 186 (bars) & \\
\hline Average Slip of No.2 Asperity & $1.7(\mathrm{~m})$ & $\mu=3.3 \times 10^{11}\left(\right.$ dyne $\left./ \mathrm{cm}^{2}\right)$ \\
\hline Average Slip of No.1 Asperity & $1.7(\mathrm{~m})$ & \\
\hline Rise Time & $0.6(\mathrm{sec})$ & Kamae and Irikura (1998) \\
\hline
\end{tabular}

* 1: Average of $\mathrm{M}_{0}$ estimated by Kanamori (1973) and Kikuchi et al. (1998) 
断層モデル，もう1つは近距離での低倍率地震計記録に 基く菊地・他 (1999) による西下がりの正断層モデルで

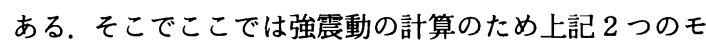
デルを想定する (Table 1). モデル 1 は逆断層モデルで, 吉岡 (1974) に従い走向 $\Phi_{\mathrm{s}} 345^{\circ}$, 傾斜角 $\delta 80^{\circ}$, すべり 角 $26^{\circ}$ を想定する. モデル 2 は菊地・他 (1999) に従い, 走向 $\Phi_{\mathrm{S}} 170^{\circ}$, 傾斜角 $\delta 70^{\circ}$, すべり角 $-10^{\circ}$ を想定する.

地震モーメントは，これまでの解析結果で $1.8 \times 10^{19}$ $\mathrm{Nm}$ から $3.3 \times 10^{19} \mathrm{Nm}$ に広がっている. ここでは, モ デル 1 とモデル 2 とあ, 地震モーメントとしてそれらの 値の中間に近い $2.6 \times 10^{19} \mathrm{~N} \cdot \mathrm{m}$ を仮定する. 全断層面積 $(S)$, 最大アスペリティの面積 $(S m)$, アスペリティ面積総 和 $(\mathrm{S} a)$ は震源インバージョン結果の解析により求めら れた地震モーメントとの関係式から与えられる.すなわ ち, 全断層面積 $S$ は (1) から $908 \mathrm{~km}^{2}$, アスペリティ面 積総和 $\left(\mathrm{S} a\right.$ ) は (3) から $204 \mathrm{~km}^{2}$, 最大アスペリティの面 積 $(\mathrm{Sm})$ は (2) から $148 \mathrm{~km}^{2}$ となる. 第 2 イベントが最 大アスペリティに対応するとし，第1イベントの面積は
アスペリティの総面積が一致するように決められる．各 アスペリティーにおける地震モーメント密度（単位面積 当たりのモーメント解放量) は, SOMERVILLE et al. (1999) の定義に従うと, 全断層域での地震モーメント密 度の 2 倍に設定される.これによると, 最大アスペリ ティーからの地震モーメントは, $2 \cdot(\mathrm{Mo} / \mathrm{S}) \cdot \mathrm{Sm}$ (ここで $M o:$ 全地震モーメント, $S$ : 全断首面積, $S m$ : 最大アスペ リティの面積), で求められる. 従って, 第 2 イベントの 地震モーメント $8.3 \times 10^{18} \mathrm{~N} \cdot \mathrm{m}$, 応力降下量 113 bars が計算される. 第 1 イベントに対しても同様の手続きで 与えると地震モーメントが $3.2 \times 10^{18} \mathrm{~N} \cdot \mathrm{m}$, 応力降下量 が 186 bars となる. この時, 第 2 イベントと第 1 イベ ントのモーメント比が 2.6:1 で菊地・他 (1999) の結果 にほほ対応している. ライズタイムは (4) から 1.2 秒と 与えられるが, 先に述べたようにこの式から決まる值は 過大評価の可能性が高い. ここでのアスペリティーのサ イズは 1995 年兵庫県南部地震とほぼ同じなので, ライ ズタイムも同じ 0.6 秒を採用する.

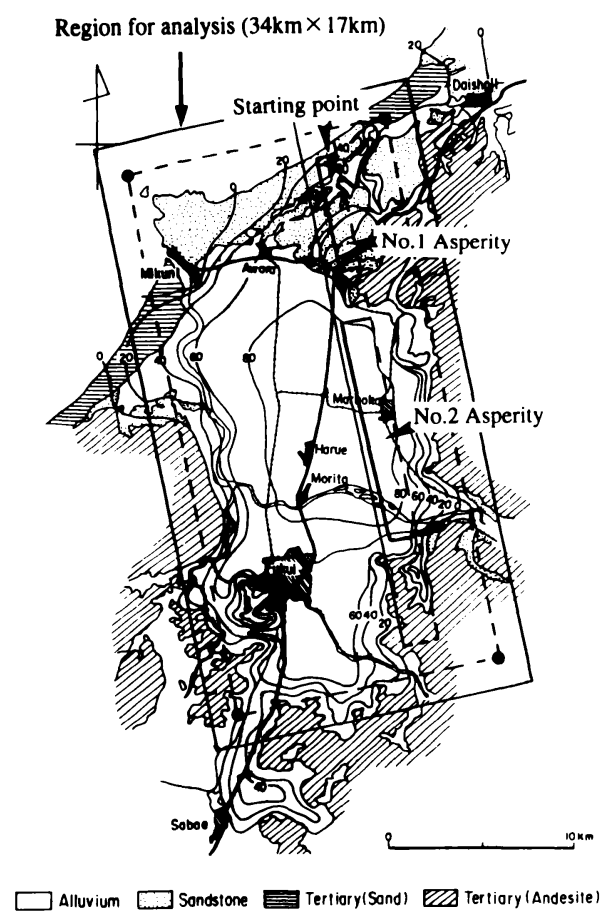

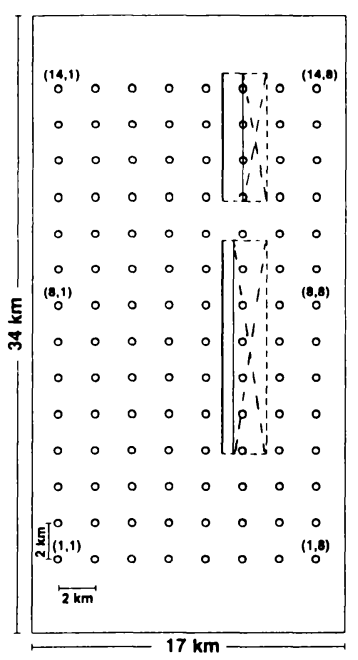

(b)

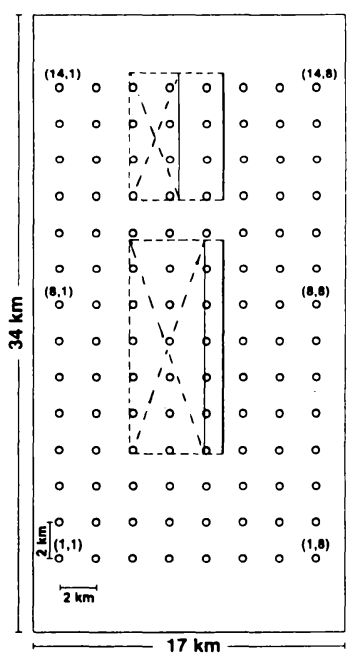

(c)

(a)

Fig. 4. Map of the Fukui basin and analyzed area. Large solid rectangle in (a) shows the analyzed area corresponding to the rectangles in the right 2 panels, (b) and (c). The broken rectangle in (a) corresponds to areas where peak velocity, acceleration, and mesured seismic intensity are shown in later figures. The locations of two asperities, No. 1 and No. 2, in (a) correspond to those for Model 1. $O^{\prime}$, $(1,1)$ to $(14,8)$ in (b) and (c) show grid points where ground motions are simulated. The two strips indicated with broken $\mathrm{X}$ mark in (b) and (c) show the locations of the two asperities for Model 1 and Model 2, respectively, in the study area. 


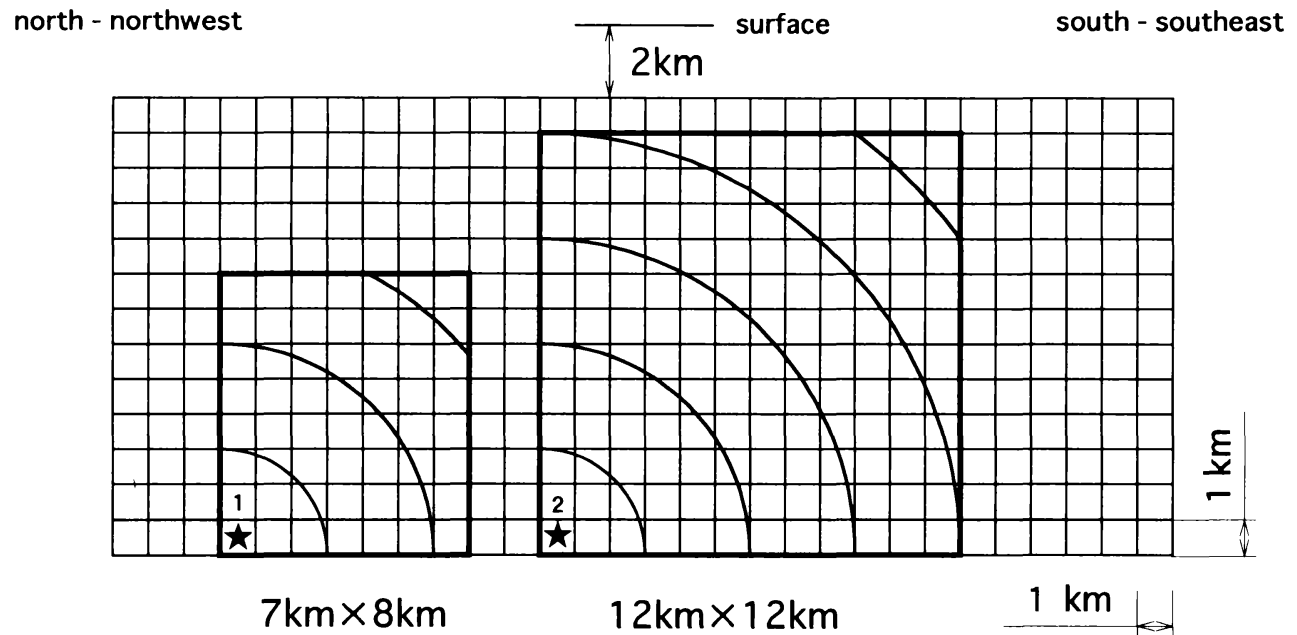

Fig. 5. Source model for simulating the 1948 Fukui earthquake. Smaller asperity corresponds to No. 1 Asperity with an area of $7 \times 8 \mathrm{~km}^{2}$ and the largest one to No. 2 Asperity with $12 \times 12 \mathrm{~km}^{2}$. Rupture starts from the left bottom at each asperity marked by $\star$. No. 2 Asperity is assumed to break 7 seconds after No. 1.
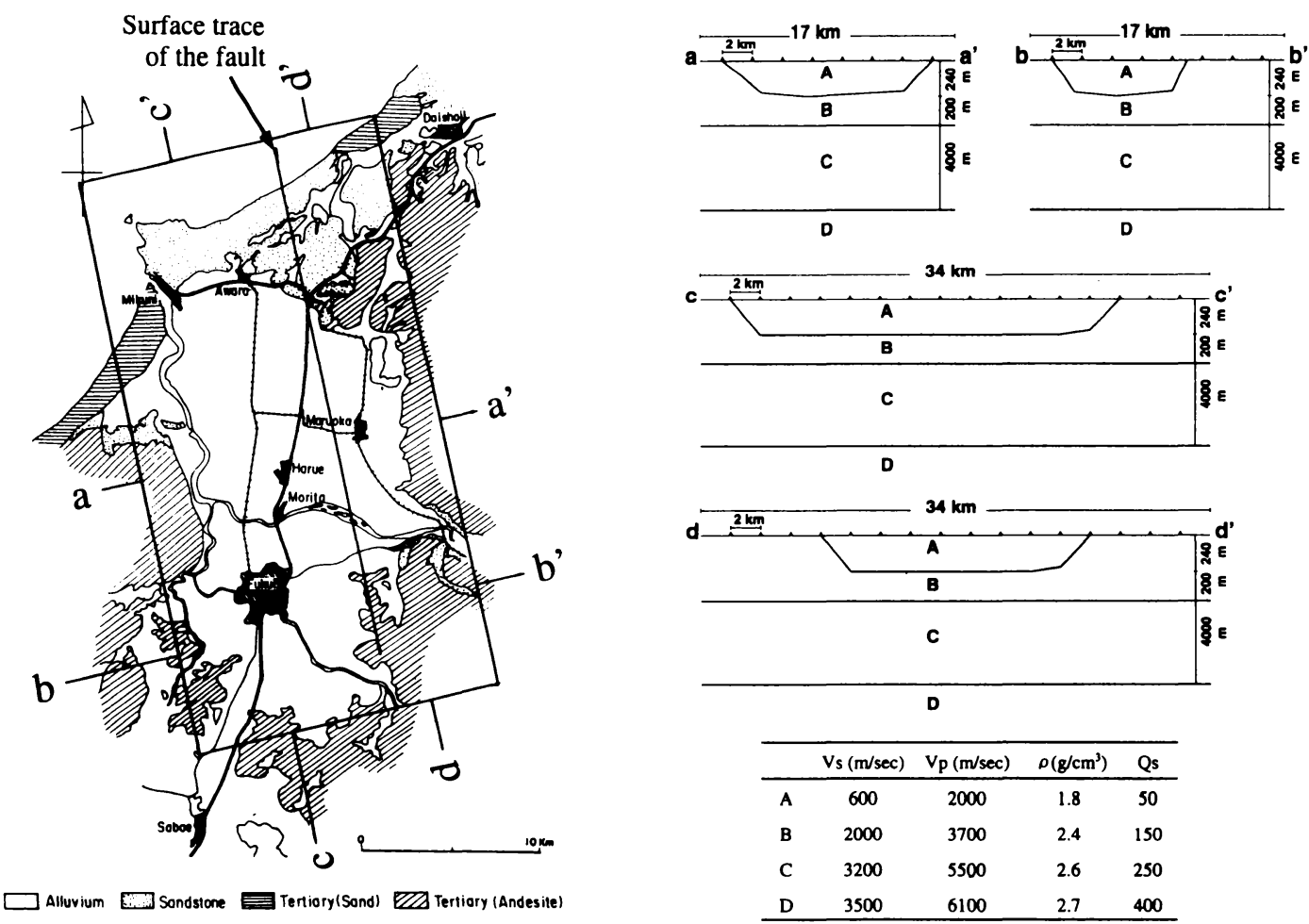

\begin{tabular}{ccccc}
\hline & $V_{s}(\mathrm{~m} / \mathrm{sec})$ & $V_{p}(\mathrm{~m} / \mathrm{sec})$ & $\rho\left(\mathrm{g} / \mathrm{cm}^{3}\right)$ & Qs \\
\hline A & 600 & 2000 & 1.8 & 50 \\
B & 2000 & 3700 & 2.4 & 150 \\
C & 3200 & 5500 & 2.6 & 250 \\
D & 3500 & 6100 & 2.7 & 400 \\
\hline
\end{tabular}

Fig. 6. Map of the Fukui basin (left) and cross sections of underground structures (right). The location of the surface fault trace is shown by a solid line in the map. $\mathrm{a}^{-\mathrm{a}^{\prime}}$ and $\mathrm{b}^{-} \mathrm{b}^{\prime}$ show cross sections in east-northeast to west-southwest direction and $c-c^{\prime}$ and $d-d^{\prime}$ show those in south-southeast to north-northwest. S wave's velocity $\left(V_{\mathrm{s}}\right)$, P wave velocity $\left(V_{\mathrm{p}}\right)$, density $(\rho)$, and $Q$ factor of $\mathrm{S}$ wave in each layer, A, B, C, and D, are shown in the right bottom. 
上記のように SOMERVILLE et al. (1999) の経験的関係 式に基くと，与えられた地震モーメントに対する平均的 震源モデルとして, 全断層面積, アスペリティの面積, そこでのモーメント解放量, などが与えられるが, 断首 の長さや幅, 断層面内での各アスペリティーの位置は与 えられない。

内陸の活断層に起因する地震はマグニチュードが 7 以上になるとその断首幅は地震発生層の厚さにほぼ等し くなることが知られている [例えば, Iто (1990)]。ここ では断層の幅 $W$ は微小地震の震源分布から推定される 地震発生層の厚さとし, 断首長さ $L$ は全断首面積 $S$ (= $L W)$ に一致するように決めることとする．平野 (1998) の福井地震断層周辺の微小地震の震源分布についての詳 細な研究を参照すると, 地震発生の深さ限界は約 17 $\mathrm{km}$ ，一方 Iто (1998) による浅さ限界は約 $2 \mathrm{~km}$ と想定 されるので,ここでは断層幅は深さ $2 \mathrm{~km}$ から $17 \mathrm{~km}$ と仮定する. 全震源断層域に対応する長さは約 $60 \mathrm{~km}$ となる，断首面内での各アスペリティーの位置は, 菊 地・他 (1999) のイベントA と B のほぼ重心 (Centroid) 位置に対応させて Fig. 4 および Fig. 5 のように定める. すなわち, 第 2 イベント $\left(12 \times 12 \mathrm{~km}^{2}\right)$ が福井地震で あっとも被害の集中した地域の直下（深さ $3 \sim 15 \mathrm{~km}$ ), 第 1 イベント $\left(7 \times 8 \mathrm{~km}^{2}\right)$ は北側の深いところ（深さ $7 \sim 15 \mathrm{~km}$ ) に存在した (Fig. 5) と仮定する. 破壊は北か ら南へ進行し, 第 1 イベントと第 2 イベントの発震時刻 の差も菊地・他 (1999) を参考に 7 秒とする.

破壊の開始点はこれまでの研究結果を参考に地震発生 層の最下部（例えば Iто (1990) 参照), 破壊速度は一定 $\left(V_{\mathrm{r}}=2.8 \mathrm{~km} / \mathrm{s}\right)$ を仮定する。このようにして想定された 震源モデルの有効性が計算された強震動之被害分布の比 較から検証される。

\section{3 地下構造のモデル化}

福井県により平成 9 年度から福井平野の地下構造が 福井県地域の活断首調查の一環として主として山地と平 野部の境界付近で反射法やボーリングなどの探査手法を 組み合わせて調べられている [荒井 (1998)]．山中・他 (1998) は福井平野の沖積および洪積層を含む地震基盤 にいたる深層堆積層の構造を微動アレイ観測を用いて推 定している.これらの深層堆積層構造をコンパイルし て, 表首地形を考慮して福井平野の 3 次元地下構造の推 定を行った. Fig. 6 の左図に示される西南西-東北東の 測線 $a-a^{\prime}$ と $b-b^{\prime}$, 北北西-南南東の測線 $c-c^{\prime}$ と $d-d^{\prime}$ における速度構造断面が Fig. 6 の右図に示される. A 層が深部堆皘首に対応し, $\mathrm{S}$ 波速度 $600 \mathrm{~m} / \mathrm{s}, \mathrm{P}$ 波速度 $2,000 \mathrm{~m} / \mathrm{s}$, 堆皘層の最深部の深さは $240 \mathrm{~m}$ で, 基盤 部は $\mathrm{B}, \mathrm{C}, \mathrm{D}$ の 3 つの層を考え， $\mathrm{S}$ 波速度はそれぞれ
$2.0 \mathrm{~km} / \mathrm{s}, 3.2 \mathrm{~km} / \mathrm{s}, 3.5 \mathrm{~km} / \mathrm{s}$ とする. 長周期地震動 （1 秒以上）を求めるための 3 次元地下構造はこのモデ ルを用いた。

短周期の地震動を評価するときには各サイトで直下の 地盤構造を平行多首構造と仮定してサイト增幅特性の計 算を行う. 地盤構造としては Fig. 6 に示された A, B, C, $\mathrm{D}$ の深層堆積層の上に沖皘層に対応するより低速度の表 酋が考慮された. 各サイトの表層厚さの空間分布は若 松・野畑 (1998) が微動の H/V の特性から推定したも のを用いた，公表されたボーリング資料を参考に，表層 の $\mathrm{S}$ 波速度, $\mathrm{P}$ 波速度, 密度, および $Q$ 值はそれぞれ $300 \mathrm{~m} / \mathrm{s}, 1,600 \mathrm{~m} / \mathrm{s}, 1.8 \mathrm{~g} / \mathrm{cm}^{3}, 30$ と仮定された.

\section{§4. 結果}

1948 年福井地震の福井平野における強震動を, 3.2 で 述べた震源断層モデルに基づき 3.3 での地下構造を考慮 しハイブリッド法（\$2 参照）により計算する. 長周期 成分のシミュレーションは 3 次元差分法を用いて, グ リッド間隔 $0.1 \mathrm{~km}$, 周波数分解限界 $1.2 \mathrm{~Hz}$ でなされ た. 震源断層は $1 \mathrm{~km} \times 1 \mathrm{~km}$ の小断層に分割され (Fig. 5), 各小断首は 1 つの等価な点震源として, 断首面内で の破壊伝播による適当な遅れ時間で地震動を生成すると して, シミュレーションがなされる [例えば, PItARKA (1998)]. 短周期のシミュレーションは, 各アスペリ ティーに 1 つずつ $1 \mathrm{~km} \times 1 \mathrm{~km}$ の断層面積と適当な応 力降下をもつ小地震を考え, 伝播媒質の $Q$ による減衰, サイト直下の 1 次元地盤構造による増幅特性を考慮し た統計的グリーン関数を計算し，その足しあわせにより 評価される.Q $Q$ 值は近畿地方の JMA87 強震計のデー夕 を用いて決められた $Q=150 f(f$ : 周波数）を用いた（川 瀬・他, 1999).

震源断層として想定されたモデル 1 とモデル 2 は, 地 震モーメント, 全断層面積, 断酋面内アスペリティーの 相対位置などの断層パラメターは同じで, 地表断層 (Surface fault trace) の位置も一致するが, 断首メカ二 ズムが異なる.モデル 1 は東落ちの逆断層であるのに対 し, モデル 2 は西落ちの正断層である. 震源パラメター の詳細は Table 1 に示される.

これらの震源モデルでストレス・ドロップは 2 つの アスペリティーでそれぞれ 186 と 113 barsであるが, アスペリティー以外での断層面でのストレス・ドロップ は約 19 barである. 2つのアスペリティーのみのモー メント解放による強震動とアスペリティー以外でのモー メント解放む加えたときの強震動を比較すると, 最大加 速度や最大速度の值はほとんど変わらない.これらのモ デルの違いによる強震動の比較は付録に示される。ここ 


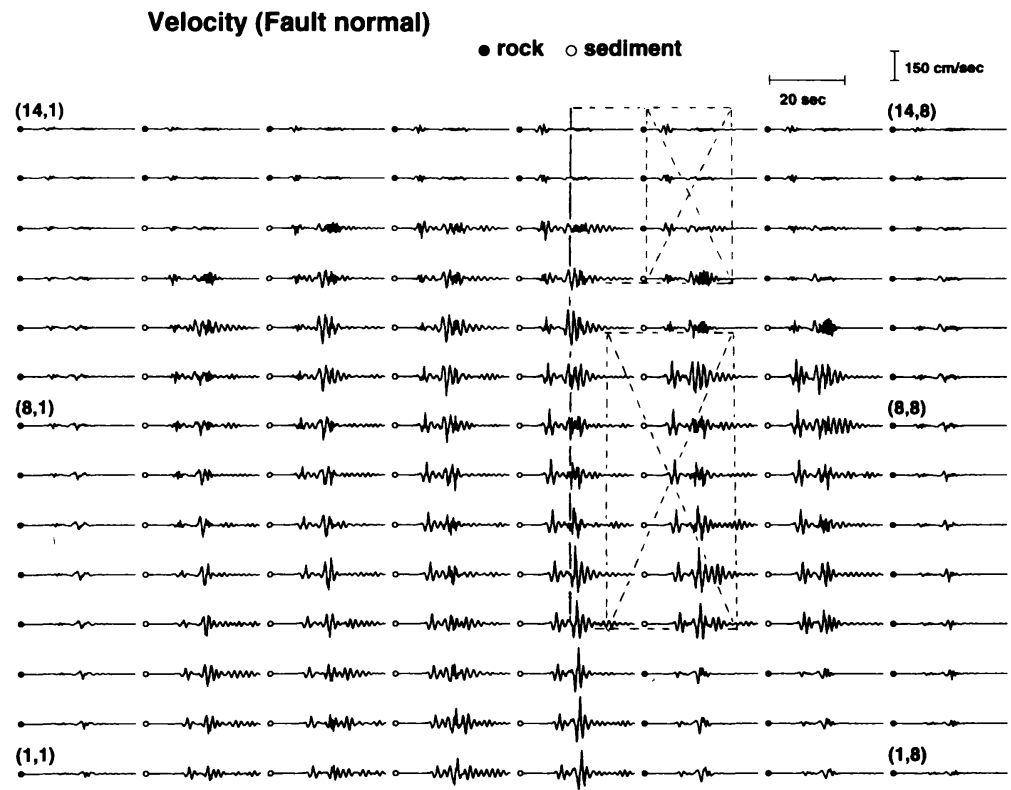

(a)

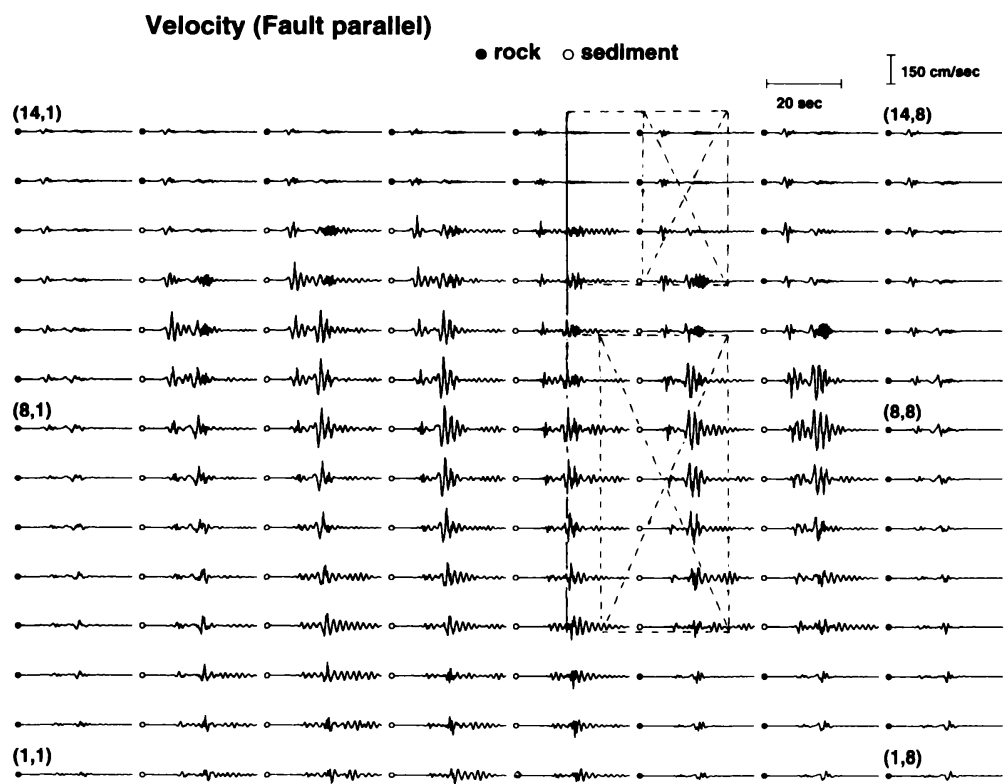

(b)

Fig. 7. (a) Distribution of simulated velocity ground motions (fault-normal component) at the grids [(1, 1) to $(14,8)$ shown in the right of Fig. 4] for Model 1 (Reverse fault model). (b) Distribution of simulated velocity ground motions (fault-parallel component). The grid coordinates are indicated by parenthesis at the left-hand of each waveform. Site conditions are classified by $\bullet$ for rock and $O$ for sediment. Amplitude level of each waveform is shown at right-upper with a bar indicating $150 \mathrm{~cm} / \mathrm{s}$.

ではアスペリティー部分のみのモーメント解放を仮定し たときの強震動の大きさとその空間分布について述べ る. 1995 年兵庫県南部地震の震源近傍の強震動はアス
ペリティーのみのすべりを想定して計算される合成波形 でよく説明できることが示されている [KAMAE and IRIKURA (1998)]. 
東下がりの逆断層を想定したモデル 1 に対して計算 された速度波形の断層直交成分および断層平行成分が Fig. 7 の (a) および (b) に示される. 各波形は Fig. 4(b) に示される地表点座標 $(1,1)$ から $(14,8)$ に対応してい る. 2 つのアスペリティーの位置は図中 $\times$ 印で示される 長方形で示される. 各座標点の地盤条件は黒丸：岩盤上 および白丸：堆積層上で示される.

断層直交成分では $100 \mathrm{~cm} / \mathrm{s}$ を越える大きな速度のパ ルス的な震動が最大アスペリティーの南端付近からその 南側に広がっている。これは破壊が北から南に進んだこ とによる指向性効果による. 最大速度振幅は最大アスペ リティーの南端付近で $148 \mathrm{~cm} / \mathrm{s}$ となっている. 最大ア スペリティの南方で大きな速度振幅が断層の西側にのみ 現れているのは断層東側は第 3 紀層の軟岩 [Fig. 4(a) 参 照]となっているからである. 一方，断層平行成分の速 度振幅は震源断層直上付近域では断層直交成分に比して 一般に小さいが，やや離れると断層直交成分よりも大き くなる．最大アスペリティの横方向では $100 \mathrm{~cm} / \mathrm{s}$ を越 える大振幅となる．岩盤上での地震動の最大速度は両成

\section{(Fault normal)}

peak velocity $(\mathrm{cm} / \mathrm{sec})$

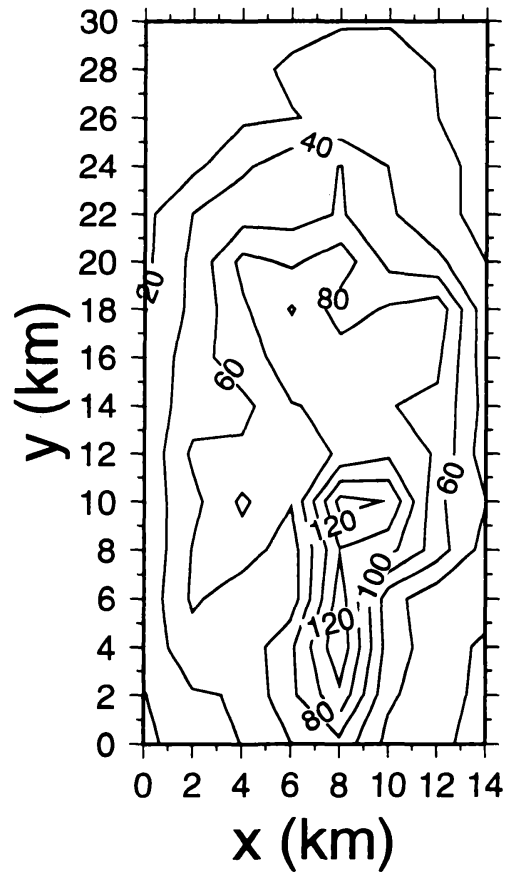

(a)
分とあ約 $35 \mathrm{~cm} / \mathrm{s}$ である.

モデル 1 に対して計算された断層直交成分および断 層平行成分の最大速度の空間分布が Fig. 8 の (a) と (b) に示される. これらのコンター図の領域は Fig. 4 の (a) に示した破線領域に対応する.今後示される地震動の空 間分布は全て同じ領域に対して示される，断層直交成分 は最大アスペリティーの南端付近が最大で, 大振幅域は その南方に広がり，一方断層平行成分は最大アスペリ ティーの両侧で大振幅となる様子が視覚的に読み取れ る. 1995 年の兵庫県南部地震に対する強震動のシミュ レーション結果 [例えば, PITARKA et al. (1998)] は最大 振幅域が震源断層と地表との交線から $1 \sim 2 \mathrm{~km}$ 堆積層 側に奇ったところであった。一方ここでの結果は, 最む 大きな速度振幅は断首直上に位置している，これは兵庫 県南部地震のときは震源断層が盆地と山地の境界に位置 していたのに対して，ここでは震源断層は堆積層の直下 の伏在断層を仮定しているからである.

断層直交成分と断層平行成分からベクトル合成された 速度の最大値の空間分布が Fig. 9(a) に示される. また

\section{(Fault parallel)}

peak velocity $(\mathrm{cm} / \mathrm{sec})$

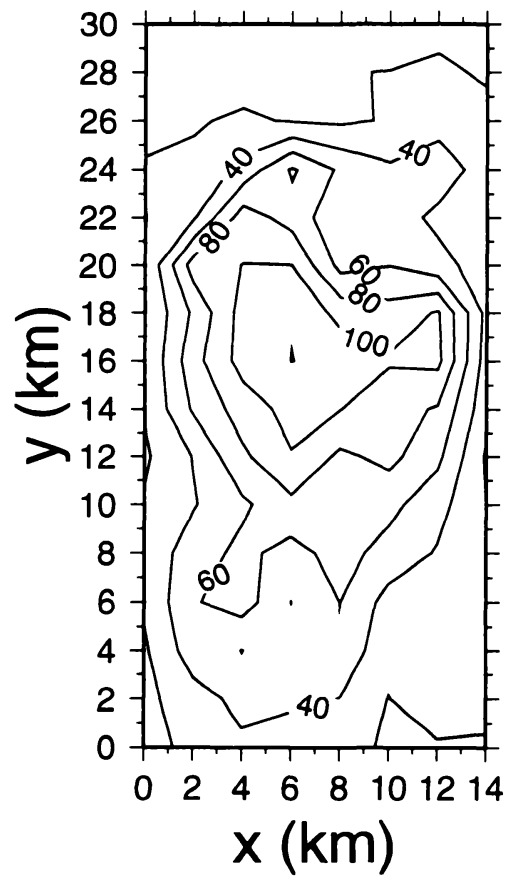

(b)

Fig. 8. Map showing contours of simulated velocity motions for Model 1 (Reverse fault model). (a) Peak velocity $(\mathrm{cm} / \mathrm{s})$ of fault-normal horizontal-motions. horizontal-motions.

(b) Peak velocity of fault-parallel 


\section{peak velocity $(\mathrm{cm} / \mathrm{sec})$}

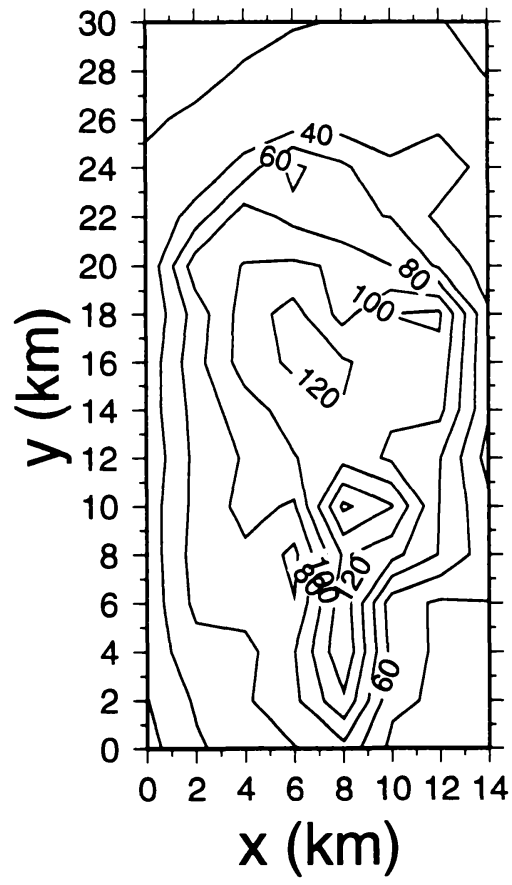

(a)

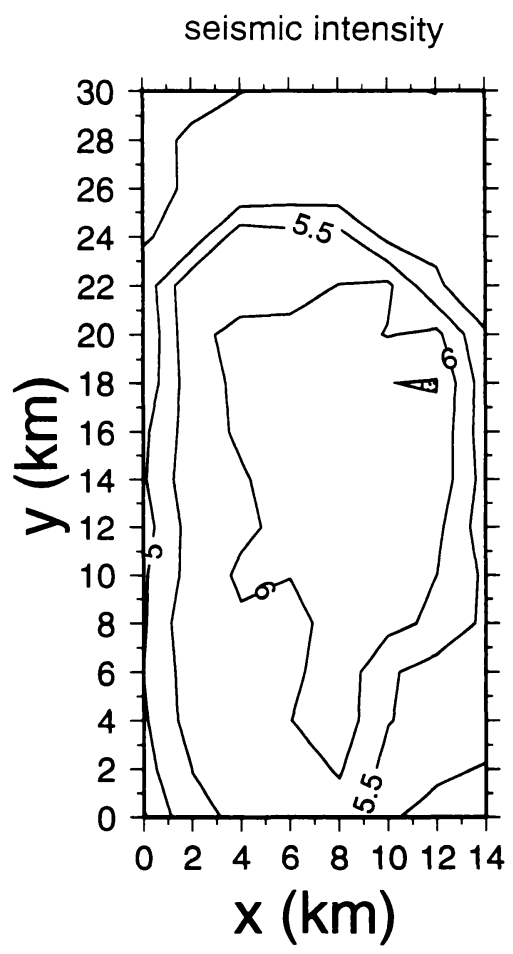

(b)

Fig. 9. Map showing contours of peak horizontal-velocity (vectorial summation of two horizontalmotions) and instrumental seismic-intensity for Model 1 (Reversal fault model). (a) Peak horizontalvelocity. (b) Measured seismic-intensity.

水平 2 成分の波形記録から計算された計測震度が Fig. 9(b) に示される. 気象庁の定義によると計測震度は 3 成 分（水平 2 成分之垂直成分）の記録を用いて計算される が，ここでは水平成分 2 成分記録のみから推定してい る. 実際上, 横ずれの卓越する震源メカニズムを想定し ているので垂直成分の影響は小さいと考えられる。計測 震度 7 は殆ど現れず, 福井平野の全壊率 30\% の地域 (Fig. 4(a) には全壊率 30\% のコンターはないので 20\% と $40 \%$ の中間を $30 \%$ と考える）は最大速度 $60 \mathrm{~cm} / \mathrm{s}$ にほぼ対応し，そしてそこでの計測震度は震度 6 弱と評 価される。

宮腰・林 (1998) は, 1995 年兵庫県南部地震の建物被 害から推定された地震動の最大速度に関する林・他 (1997) の関係式加ら震度 7 地域は最大速度 $100 \mathrm{~cm} / \mathrm{s}$ 以上であるという結果を報告している。，一方諸井・他 (1998) は 1948 年福井地震の全壊率 $30 \%$ を与える地震 動強さは 1995 年兵庫県南部地震の全壊率 $10 \%$ に相当 するとしている，兵庫県南部地震の全壊率 $10 \%$ の地域 の最大速度は宮腰・林 (1998) によると約 $80 \mathrm{~cm} / \mathrm{s}$ とな る.これらの結果が正しいとすると，ここでのモデル 1
による強震動は若干過小評価と考えられる.

西落ちの正断層を想定したモデル 2 に対する合成速 度波形の断層直交成分および断首平行成分が Fig. 10 の (a) と (b) に示される. 図中で示される記号の意味は Fig. 7(a), (b) と同じである. 断層直交成分および断層平行成 分の最大速度の分布は Fig. 11 の (a) および (b) に示され る.

モデル 2 では震源断首の上盤側に福井平野中心部が 位置することになるため, 平野全体に大きな速度振幅の 強震動が広がっている. またモデル 2 はモデル 1 よりも 傾斜角が緩やかですべり角が小さいため，全体として断 層直交成分が小さく断層平行成分が大きい傾向が見られ る. 断首直交成分は破壊伝播の前方指向性効果のため最 大アスペリティーの先端付近で最大速度振幅 $170 \mathrm{~cm} / \mathrm{s}$ [Fig. 10(a) で座標点 $(4,6)$ ] となる. 断層平行成分は断層 面の上盤側に大きな速度振幅の震動が広がり, 最大で約 $227 \mathrm{~cm} / \mathrm{s}$ [Fig. 10(b) で座標点 $(9,4)$ ）なる. 岩盤上の 地震動の最大速度はモデル 1 と同様約 $35 \mathrm{~cm} / \mathrm{s}$ である.

断首直交成分と断層平行成分のベクトル合成の最大值 を最大速度值としてその空間分布が Fig. 12(a) に示さ 


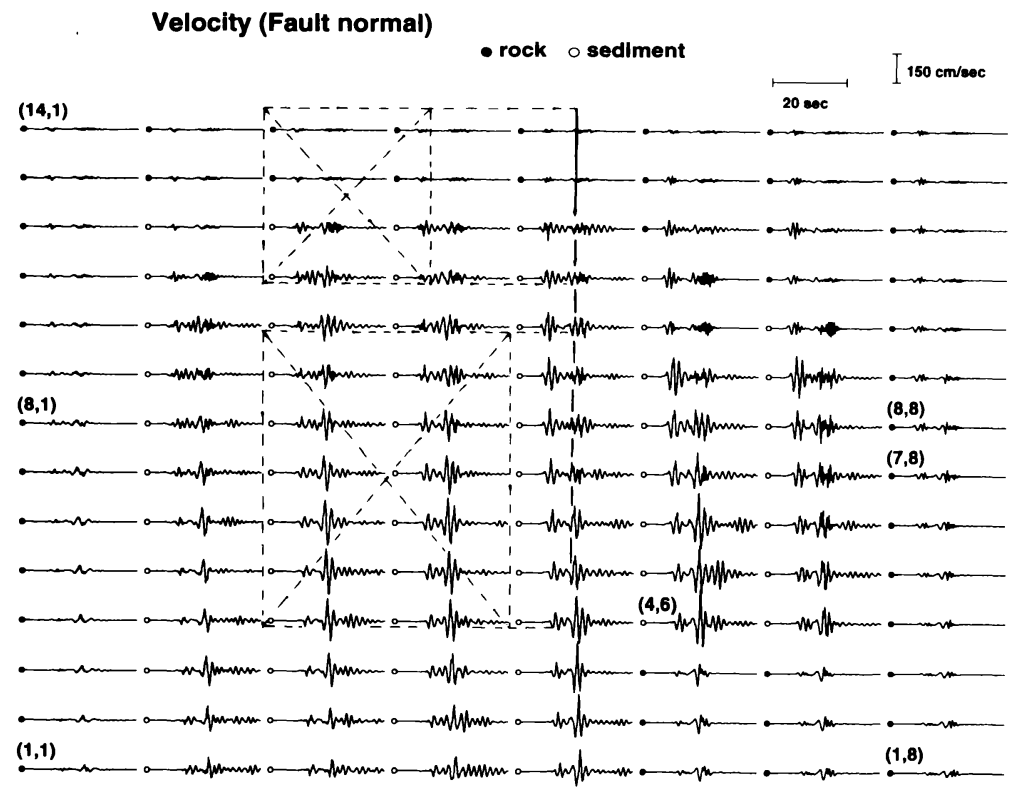

(a)

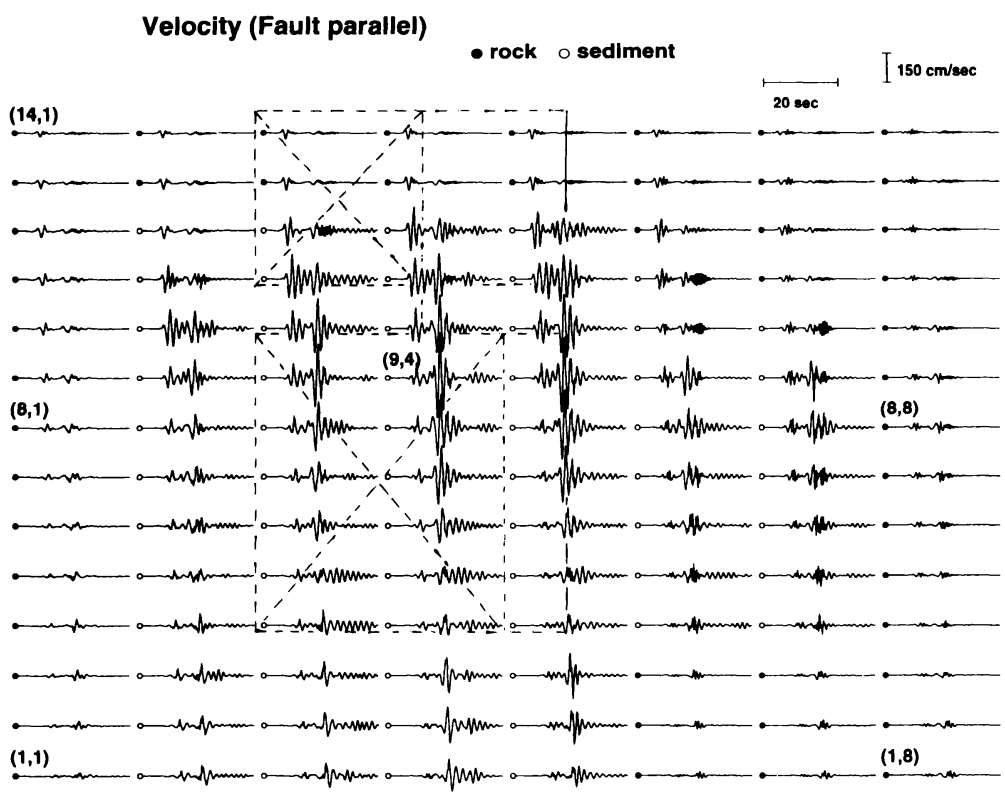

(b)

Fig. 10. (a) Distribution of simulated velocity ground motions (fault-normal component) at the grids $[(1,1)$ to $(14,8)$ shown in the right of Fig. 4] for Model 2 (Normal-fault model). (b) Distribution of simulated velocity ground motions (fault-parallel component). The grid coordinates are indicated by parenthesis at the left-hand of each waveform. Site conditions are classified by for rock and $\bigcirc$ for sediment. Amplitude level of each waveform is shown at right-upper with a bar indicating $150 \mathrm{~cm} / \mathrm{s}$. 
れる. また水平 2 成分の波形記録から計算された計測震 度が Fig. 12(b) に示される. 計測震度はモデル 1 の場合 と同じ方法で計算された。 モデル 1 に対する計測震度 マップ [Fig. 9(b)] では震度 7 の領域はほとんど現れな かったが，モデル 2 に対するマップ [Fig. 12(b)] では震 度 7, すなわち計測震度 6.5 以上，の領域が福井平野の 中心部に現れる. Fig. 12 の (a) で最大速度 $160 \mathrm{~cm} / \mathrm{s}$ 以 上の地域が (b) で計測震度 7 と評価される地域にほぼ対 応するように見える。しかしながら, 計測震度 7 は兵庫 県南部地震でも殆ど記録されたわけでもないので, 震度 7 と震度 6 強の違いは相対的な大きさの違い以上の意味 はないと考える。ここではむしろ全壊率と最大速度の関 係に注目する.Fig. 4 の (a) の全壊率 30\% の領域は, Fig. 12(a) に示される計算された地震動の最大速度の 80〜 $100 \mathrm{~cm} / \mathrm{s}$ のコンターにほぼ対応し，Fig. 12(b) で 計測震度としてはほぼ震度 6 強と評価された領域に対 応する。ここでの最大速度値は先に述べたように宮越・ 林 (1998) による 1995 年兵庫県南部地震の時の全壊率 $10 \%$ 以上の地域の最大速度值にほぼ対応する.

\section{(Fault normal)}

peak velocity $(\mathrm{cm} / \mathrm{sec})$

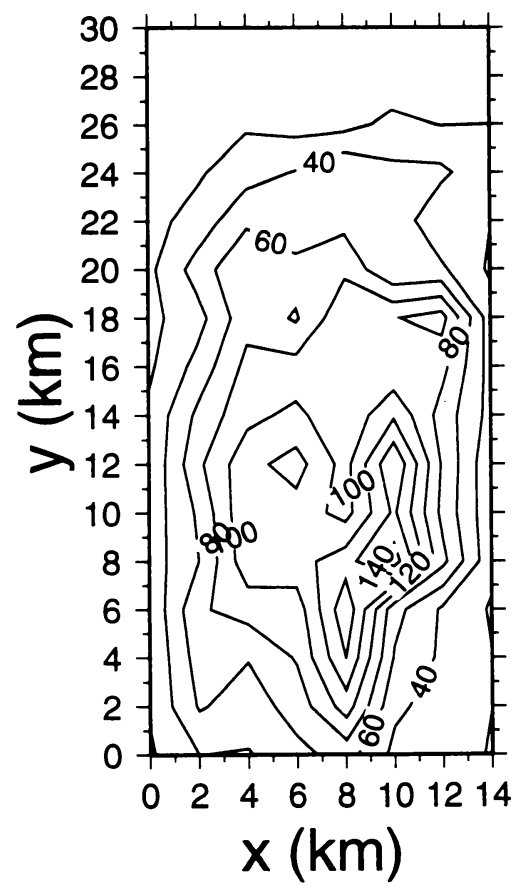

(a)
モデル 2 に対して計算された福井平野の強震動の擬 似速度レスポンス・スペクトルが 1995 年兵庫県南部地 震の時の観測值と Fig. 13 で比較される. 図中太実線は 断層直交成分の中で最大速度值を与える合成波形 [Fig. 10(a) で座標点 $(4,6)]$ のレスポンス・スペクトル, 太破 線は断層平行成分の中で最大速度となる合成波形 [Fig. 10(b) で座標点 $(9,4)]$ のレスポンス・スペクトルを示 す. 岩盤サイトの合成波形 [断層直交方向, Fig. 10(a) で 座標点 $(7,8)]$ のレスポンス・スペクトルは二点鎖線で 示される.

比較のため, 1995 年兵庫県南部地震の時「震災の帯」 内に位置する鷹取 (TKT) での強震動観測記録および東 灘区の福池小学校 (FKI) での再現波形の擬似速度レスポ ンス・スペクトルが Fig. 13 に細実線と細破線で示され る.この結果は 1948 年福井地震のとき福井平野で生じ た強震動は 1995 年兵庫県南部地震の「震災の帯」での 強震動をやや上回る応答特性を有していたことを示唆し ている.

モデル 2 に対して計算された加速度波形の断層直交

(Fault parallel)

peak velocity $(\mathrm{cm} / \mathrm{sec})$

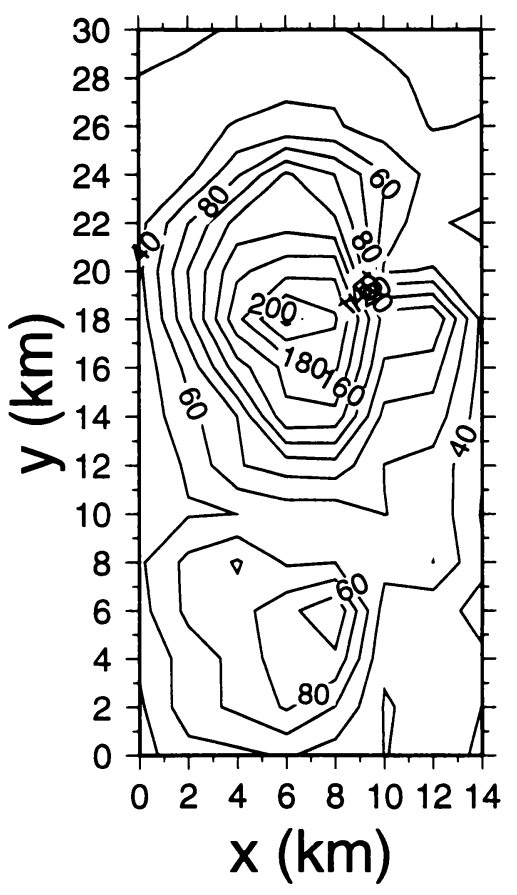

(b)

Fig. 11. Map showing contours of simulated velocity motions for Model 2 (Normal-fault model). (a) Peak velocity $(\mathrm{cm} / \mathrm{s})$ of fault-normal horizontal-motions. (b) Peak velocity of fault-parallel horizontal-motions. 


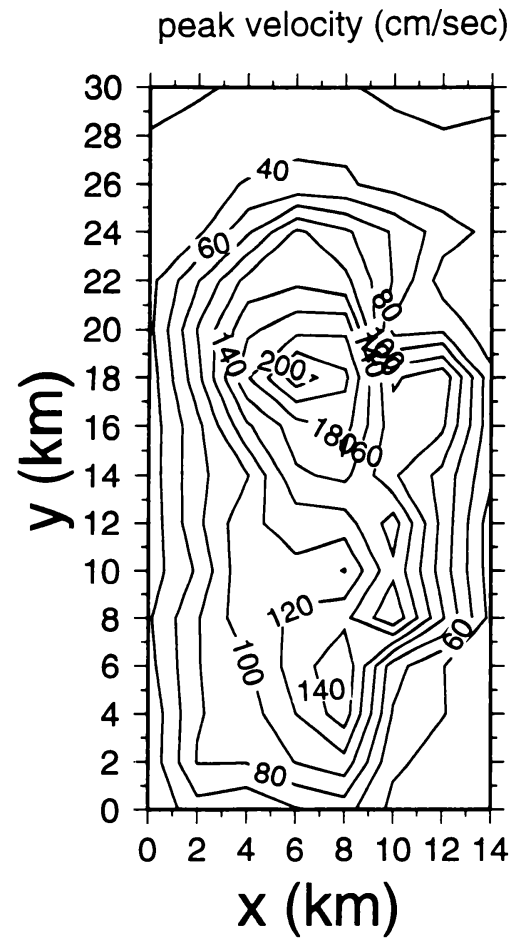

(a)

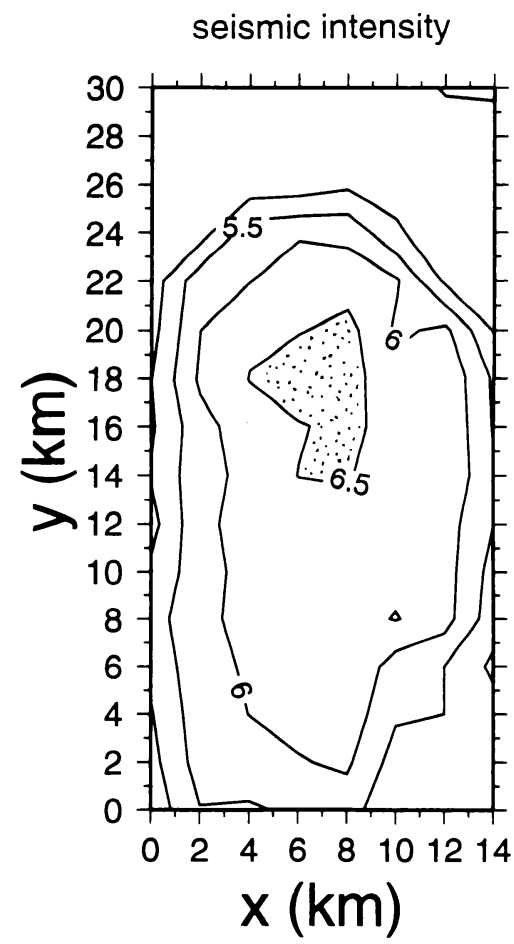

(b)

Fig. 12. Map showing contours of peak horizontal velocity (vectorial summation of two horizontalmotions) and instrumental seismic-intensity for Model 2 (Normal-fault model). (a) Peak horizontalvelocity. (b) Measured seismic-intensity.

\section{PSEUDO VEL. SPECTRA LOG( KINE )}

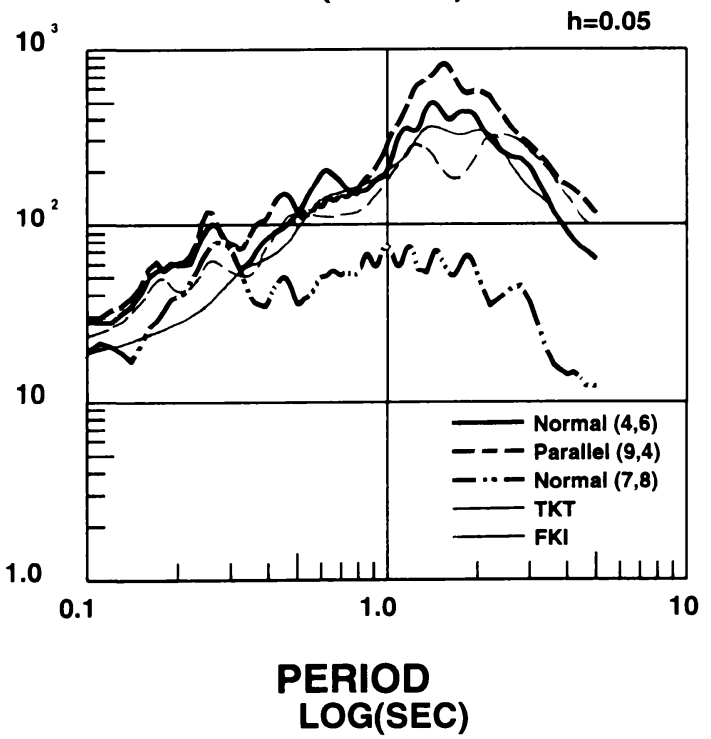

Fig. 13. Pseudo velocity response spectra of simulated ground motions on sediments [thick solid line for the normal component at grid $(4,6)$ and thick broken line for the parallel component at grid $(9,4)]$ and on rock [thick broken line at grid $(7,8)$ ] for Model 2. For comparison the pseudo velocity response spectra of the observed motion at Takatori (TKT) and simulated motion at Fukui Junior School (FKI) within the damage belt during the 1995 Hyogoken Nanbu Earthquake are shown with thin solid and broken lines. 


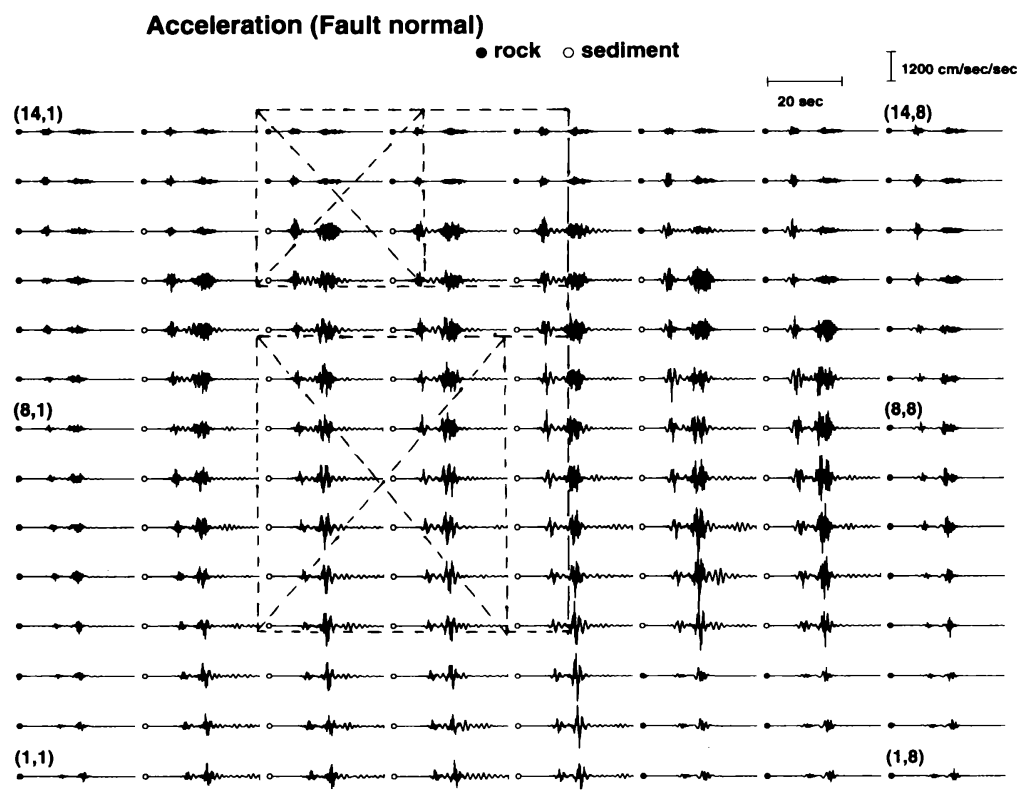

(a)

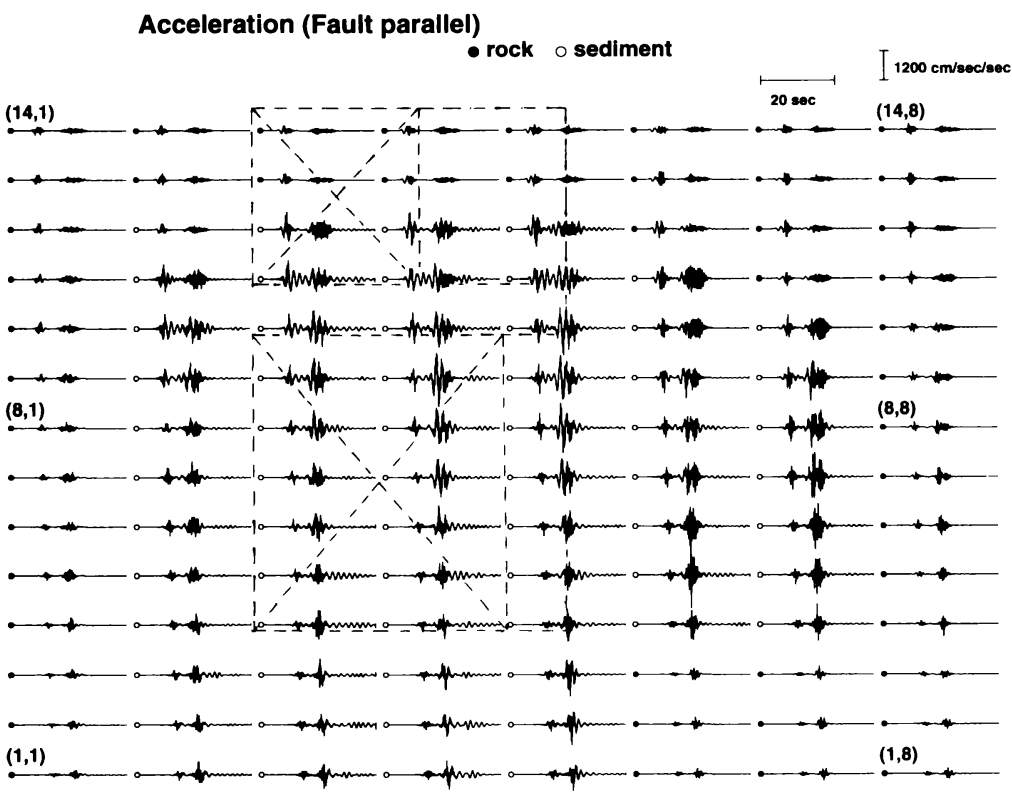

(b)

Fig. 14. (a) Distribution of simulated acceleration ground motions (fault-normal component) at the grids $[(1,1)$ to $(14,8)$ shown in the right of Fig. 4] for Model 2 (Normal-fault model). (b) Distribution of simulated acceleration ground motions (fault-parallel component). The grid coordinates are indicated by parenthesis at the left-hand of each waveform. Site conditions are classified by $\bigcirc$ for rock and $\bigcirc$ for sediment. Amplitude level of each waveform is shown at right-upper with a bar indicating 1,200 gals.

成分および断層平行成分が Fig. 14 の (a) および (b) に示 される. 最大加速度值が大きくなる領域は最大速度値の 場合と同様に，一般的に断層直交方向は破壊伝播の指向
性効果により最大アスペリティーの南端からさらにその 南方の領域, 断層平行方向は上盤側の堆積層の領域とな る. 一方で, 最大加速度值は, 短周期での表層による増 
(Fault normal)

peak velocity $(\mathrm{cm} / \mathrm{sec})$

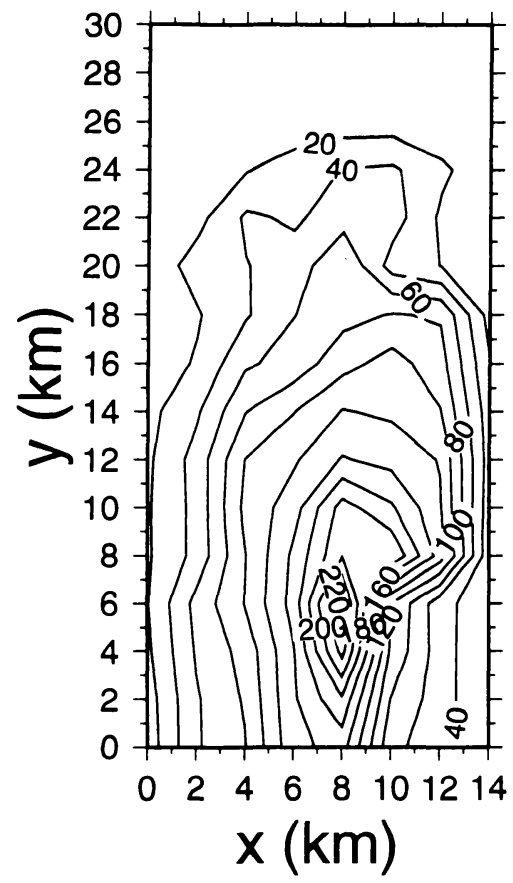

(a)
(Fault parallel)

peak velocity $(\mathrm{cm} / \mathrm{sec})$

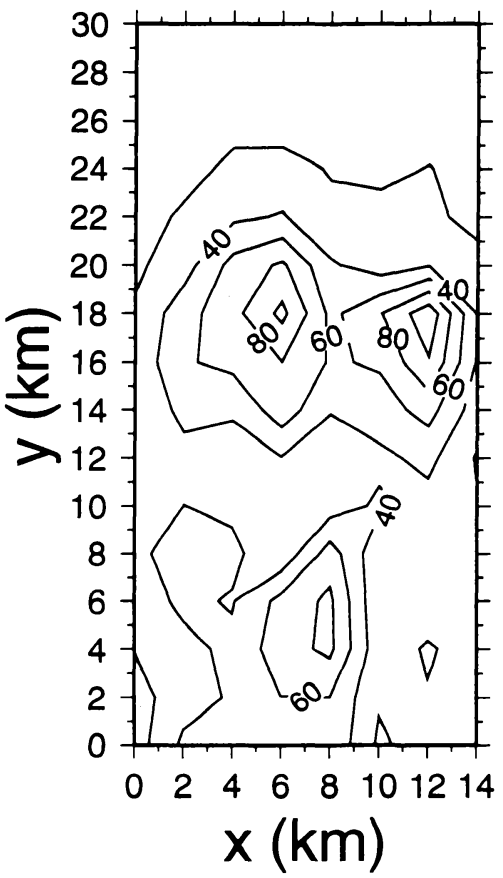

(b)

Fig. 15. Map showing contours of simulated velocity motions for the pure strike-slip source model $\left(\operatorname{dip}=90^{\circ}\right.$, rake $\left.=0^{\circ}\right)$. (a) Peak velocity $(\mathrm{cm} / \mathrm{s})$ of fault-normal horizontal-motions. (b) Peak velocity of fault-parallel horizontal-motions.

幅度が平野中央部で大きく周䢌の岩盤地域で急速に小さ くなる，いわゆるサイト特性の影響を強く受けている. そのため, 地震動の加速度の最大值は短周期成分に支配 され, 破壊伝播の指向性の効果は最大速度に比べると相 対的に小さくなっている. 実際に 1995 年兵庫県南部地 震のときも速度震動は指向性の効果を顕著に示したが, 加速度震動は指向性効果を比較的受けにくかった。

ここでの計算では表層による増幅特性は大振幅に対し ても線形を仮定しているので軟弱地盤上の最大加速度の 値そのものは過大に評価されていると考えられる. 加速 度の大きさを議論するには非線型効果を考慮した表層の 地震動応答の計算が必要とされる.

\section{§5. 議論}

モデル 1 (逆断層モデル, 傾斜角は東に $80^{\circ}$ ) およびモ デル 2 (正断層モデル, 傾斜角は西に $70^{\circ}$ ) とも, 震源断 層面は鈆直から若干傾き, すべりあ水平に加えて少しだ け鉛直成分を含むものとなっている，比較のため，震源 モデルとして傾斜角が $90^{\circ}$, すべり角が $0^{\circ}$ の純粋な左横
ずれ断層を想定し，その他の震源パラメターはすべて同 じと仮定した場合に対する強震動の計算を行う。この震 源モデルを以後純横ずれ震源モデルとよぶ. 計算された 速度波形の最大速度值の空間分布が断層直交成分および 断層平行成分について Fig. 15 の (a) および (b) にそれぞ れ示される. 断層直交成分の最大速度の最も大きい領域

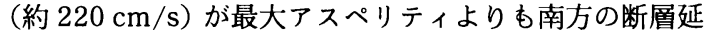
長上にあらわれる. 断層平行成分は断層直交成分に比べ て一般に小さいが, 最大アスペリティの直上では小さく やや離れたところ $(3 \sim 4 \mathrm{~km})$ で少し大きな振幅を持つ 目玉が出来る. 全体として速度振幅の大きい領域 (60 $\mathrm{cm} / \mathrm{s}$ 以上）は最大アスペリティの南方に集中し，その 範囲むモデル 1 やモデル 2 に比べて狭くなっている. 速 度振幅の大きいところを全壊率の最も高い領域 [Fig. 4(a) で 80\% の領域]に一致させるにはアスペリティー の位置をより北方に約 $10 \mathrm{~km}$ 程度移動する必要がある が，そうすると発震点が海岸線を越えて沖あいとなり浜 田 (1987) による本震の震央位置から大きくずれてしま う. 被害分布のパターン [Fig. 4(a)] は, 震源断層面が傾 


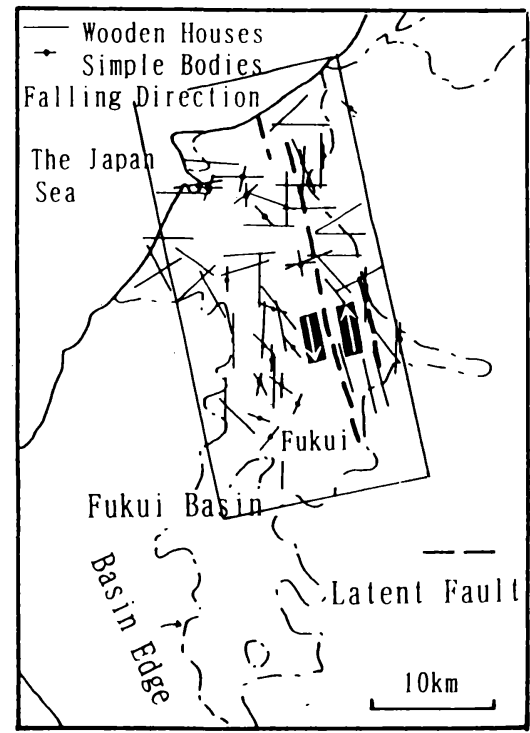

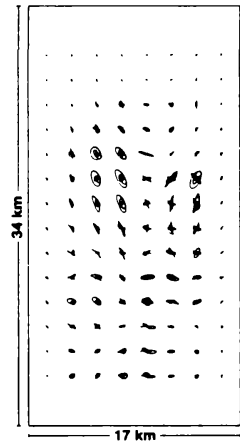

(b)

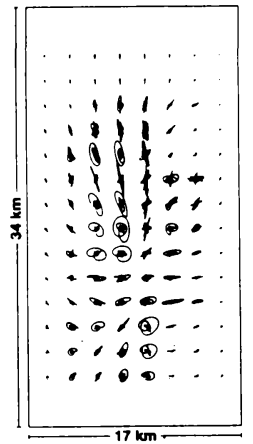

(c)

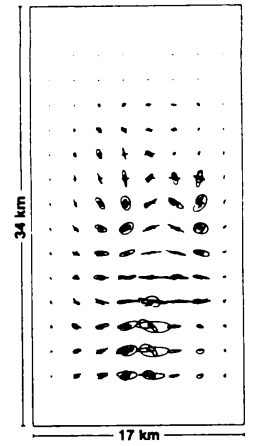

(d)

(a)

Fig. 16. (a) Direction of fall of simple bodies (short bars) and collapsed wooden houses (long bars), and the latent earthquake faults (broken curves) [after TAKemura (1998)]. (b), (c), and (d): Particle motion diagrams of simulated velocity motions for Model 1 (b), Model 2 (c) and for the pure strike-slip source model (d).

斜し，すべりも横ずれのみでなく縦ずれもあるとする震 源モデルの方がよく説明できると考えられる.

福井地震の被害調査では全壊率に加えて墓石等の単体 の転倒方向や家屋・煙突の倒壊方向が Fig. 16(a) のよう に記載されている [北陸震災調查特別委員会 (1951), 武 村他 (1998)]. 武村他 (1998) あ指摘しているようにこれ らの構造物の倒壊方向はかなりばらつきがあり一定の方 向性は見出しがたいが, 宮武 (1999) は倒壊方向に規則 性があると考え断層近傍地震動のシミュレーションによ りアスペリティーの破壊伝播方向から説明可能としてい る. ここでのモデル 1 , モデル 2 および純横ずれ震源モ デルによる断層近傍での地震動の粒子軌跡 (particle motion) が Fig. 16 の (b), (c), および (d) に示される. (b), (c), (d) の長方形の計算領域は (a) で断層近傍の長方 形で囲まれた領域に一致させている．Fig. 16(a) では震 源断層の西側の平野部における構造物の転倒方向は北寄 りでは断層直交方向が卓越し，南に行くにしたがって断 首に平行となり，さらに南ではばらついているがまた断 層に傾いた方向が卓越しているようにみえる. モデル 1 による地震動の粒子軌跡 (b) は平野中央北部寄りでは明 瞭でないが, 中央付近で断層平行方向, さらに南にくる と断層直交方向に変化しており, 観湘事実に似た傾向を 示している. モデル 2 のそれ (c) は平野中央部で断層平 行方向が卓越し, 南よりで傾いている点で観測に一致の
傾向があるが，北よりの領域では一致しない，純横ずれ 震源モデルによる地震動は平野中央部北寄りでは断首平 行方向を示して観測に一致の傾向もあるが, 中央部から 南にかけて断首直交方向に震動しており, 観測事実と一 致しない，断層近傍での地震動の粒子軌跡からどのモデ ルがベストかの結論は困難である.

\section{§6. まと め}

(1) 1948 年福井地震のときの強震動を推定するため に震源のモデル化を行った，地震モーメントは，これま で地殼変動データや近地の強震変位記録などから推定さ れ報告されている値の中間的な値 $2.6 \times 10^{26} \mathrm{dyne} \cdot \mathrm{cm}$ と考え, SOMERVILLE et al. (1999) によるアスペリティ に対するスケーリング則を適用して，標準的な不均質断 層モデルが想定された. 震源断首面として, 吉岡 (1974) に基く逆断層モデル（モデル 1 : 走向 $345^{\circ}$, 傾斜角 $80^{\circ}$, すべり角 $26^{\circ}$ ) と菊地・他 (1999) に基く正断層モデル （モデル 2: 走向 $170^{\circ}$, 傾斜角 $70^{\circ}$,すべり角 $-10^{\circ}$ ) が採 用された，断層面内の主要なアスペリティーは，菊地・ 他 (1999) に従い大小 2 つで, はじめに小さいアスペリ ティーが破壊し，次に最大アスペリティが破壊したと考 える. それぞれのアスペリティーの領域の広がり, およ びそこからのモーメント解放量は SOMERVILLE et al. (1999)にしたがって想定された. 最大アスペリティは面 
積 $148 \mathrm{~km}^{2}$, 平均すべり量 $1.7 \mathrm{~m}$, 応力降下量 113 bars となる.

（2）強震動はハイブリッド法で計算された．（1) で定 義されるモデル 1 (逆断層モデル) に対して, 推定され た平野部での強震動の最大速度は約 $150 \mathrm{~cm} / \mathrm{s}$ で, 計测 震度 7 の地域は殆どない，家屋の全壊率が $30 \%$ 以上の 地域での最大速度が $60 \mathrm{~cm} / \mathrm{s}$ 以上となり, そこでの計 测震度として震度 6 弱と評価される. モデル 2 (正断層 モデル）を想定したとき平野部での強震動の最大速度は $200 \mathrm{~cm} / \mathrm{s}$ を越えるところが現れ, 最大速度 $160 \mathrm{~cm} / \mathrm{s}$ 以上の地域がほぼ計測震度 7 に対応する. 家屋の全壊率 が $30 \%$ 以上の地域での最大速度が $80 \mathrm{~cm} / \mathrm{s}$ 以上とな り，そこでの計測震度として震度 6 強と評価される.

(3) 1948 年福井地震のときの全壊率 $30 \%$ の地域は 1995 年兵庫県南部地震の時の木造家屋の全壊率 $10 \%$ の地域に対応する [諸井・他 (1998)] という結果を参考 にすると, 福井地震のとき全壊率 $30 \%$ の地域の強震動 の最大速度は $80 \mathrm{~cm} / \mathrm{s}$ 以上 [宮越・林 (1998)] と考えら れる. モデル 1 に対する福井平野中心部の強震動は若干 過小評価と考えられるが, モデル 2 に対する強震動の最 大速度は兵庫県南部地震の観測からの推定值とよく一致 する.この結果は, 地震モーメントと震源断層の幾何学 的形状が適切に与えられれば, SoMERVILLE et al. (1999) による断層すべりの不均質モデルが強震動予測に有効な ことを示している.

（4）傾斜角 $90^{\circ}$ ですべり角 $0^{\circ}$ の左横ずれのみからな る震源モデルを想定し, アスペリティの大きさと位置, 応力降下量を標準化モデルと同じとすると, 強震動の速 度の大きい領域は最大アスペリティの直上ではなくその 南方に現れる.このモデルは本震の震央と被害分布の幾 何学的関係と対応しない.

（5）想定された福井地震の震源モデルに対して推定 された強震動の最大速度の大きい領域（モデル 2 で例え ば $80 \mathrm{~cm} / \mathrm{s}$ 以上）は福井平野のほぼ全域に広がってお り, 1995 年兵庫県南部地震のときの「震災の帯」のよう な震源断層に平行した帯状の被害集中域は現れない。こ れは, 福井地震の震源断層は厚い堆積層の下にあったた め, 非常に広い領域で振幅の大きい強震動が生成された ためと考えられる.このことは被害予測を行うためには 震源のモデル化と同時に想定する震源断層を取り巻く堆 積層の 3 次元構造の把握が重要なことを示している.

\section{謝辞}

本論文をまとめるにあたり, 解析途中の震源パラメ ターをお教えいただいた菊地正幸氏, 兵庫県南部地震の 全壊率と最大速度の関係についてコメントいただいた林
康裕氏に深く感謝します，本論文は查読者武村雅之氏お よび宮武 隆氏の適切なコメントにより大きく改善され ました。

本研究の一部は文部省科学研究費補助金 (課題番号 08248111）の補助を受けて実施されたものです.

\section{文献}

Asada T. and Z. Suzuki, 1949, On microearthquakes having accompanied aftershocks of the Hukui earthquake of June 28, 1948, Geophysical Notes, Geophys. Inst., Univ. of Tokyo, Japan, 2(16), 1-14.

荒井克彦, 1998, 福井平野東緣断層帯調查報告, 日本地 震学会講演予稿集, A05.

Boore, D. M., 1983, Stochastic simulation of highfrequency ground motions based on seismological models of the radiated spectra, Bull. Seism. Soc. Am., 73, 1865-1894.

Bouchon M., 1981, A simple method to calculate Green's function for elastic layered media, Bull. Seism. Soc. Am., 71, 959-971.

GRAvES, R. W., 1996, Simulating seismic wave propagation in $3 \mathrm{D}$ elastic media using staggered-grid finite differences, Bull. Seism. Soc. Am., 86, 10911106.

長谷川洋平, 1986, 非線形インバース法を用いた湘地 データの解析：内陸型地震の断層モデル, 東京大学理 学系研究科地球物理学専門課程修士論文.

浜田信生, 1987, 日本列島の内陸部に発生した被害地震 に伴う地震活動の再調查とその地震学的意義, 気象研 究所研究報告, 38,77-156.

林 康裕・宮越淳一, 1997, 1995 年兵庫県南部地震の 建物被害に基く最大地動速度に関する考察, 日本建築 学会構造系論文報告集, 502, 61-68.

平野憲雄, 1998 , 地震デー夕の高度有効利用のための地 震観測・解析システムの構築, 京都大学大学院理学研 究科博士論文, $120 \mathrm{pp}$.

北陸震災特別委員会, 1951, 福井地震震害調查報告, II 建築部門, $287 \mathrm{pp}$.

ITo, K., 1998, Seismogenic layer, reflective lower crust, surface heat flow and large inland-earthquakes, submitted to Tectonophysics.

釜江克宏・入倉孝次郎・福知保長, 1991 , 地震のスケー リング則に基いた大地震時の強震動予測, 日本建築学 会構造系論文報告集, 430, 1-9.

KAMAE, K. and K. IRIKURA, 1998, Source model of the 1995 Hyogo-ken Nanbu earthquake and simulation of near-source ground motion, Bull. Seism. Soc. Am., 88, 400-412.

Kamae, K., K. Irikura and A. Pitarka, 1996, A Technique for simulating strong ground motion using hybrid Green's function, Bull. Seism. Soc. Am., 88, 357-367.

KANAMORI, H., 1973, Mode of strain release associated with major earthquake in Japan, Ann. Rev. Earth Planet. Sci., 1, 213-239. 
KAwASE, H., 1996, The cause of the damage belt in Kobe. "The basin-edge effect," constructive interference of the direct $\mathrm{S}$ wave with the basin-induced diffracted/Rayleigh waves, Seism. Res. Lett., 67, 25-35.

川瀬 博・松島信一・佐藤智美 - 伏見 実・巽 誉樹, 1999, JMA87 型強震計の観測記録に基いた震源・伝 播経路・サイトの各特性の分離, 日本建築学会大会学 術講演梗概集, 1999.

菊地正幸・中村 操 - 山田 真・伏見 実・巽 誉樹・ 吉川一光, 1999,1948 年福井地震の震源パラメー ター一1 倍強震計記録の解析一, 地震 $2,52,121-128$.

IrIKuRA, K., 1986, Prediction of strong acceleration motion using empirical Green's function, Proc. 7th Japan Earthq. Eng. Symp., 151-156.

Irikura, K., T. Iwata, H. Sekiguchi, A. Pitarka and K. KAMAE, 1996, Lesson from the 1995 Hyogo-ken Nanbu earthquake: why were such destructive motions generated to buildings?, Journal of Natural Disaster Science, 18-2, 99-127.

宮越淳一・林 康裕，1998，被災デー夕に基づく木造建 物群の耐震性能評価, 第 3 回都市直下地震災害総合シ ンポジューム論文集, 315-318.

宮武 隆, 1999, 1948 年福井地震の強震動一建築物・ 墓石等の倒壊方向之震源過程一, 地震 $2,52,151-$ 160.

諸井孝文・武村雅之・宮村正光，1998，1995 年兵庫県 南部地震による住家全壊率と気象庁震度の関係, 地球 惑星科学関連学会合同大会予稿集, Sm-034.

Pitarka, A., K. Irikura, T. Kwata and H. Sekiguchi, 1998, Three-dimensional simulation of the nearfault ground motion for the 1995 Hyogo-ken Nanbu (Kobe), Japan, earthquake, Bull. Seism. Soc. Am., 88, 428-440.
鷺谷 威, 1999,1948 年福井地震 $(M=7.1)$ に伴う地殼 変動之震源断層モデル, 地震 2, 52, 111-120.

佐藤良輔 (編著)，1989，日本の地震断層パラメター・ ハンドブック，鹿島出版会, $390 \mathrm{pp}$.

Somerville, P., K. Irikura, R. Graves, S. Sawada, D. Wald, N. Abrahamson, Y. Iwasaki, T. Kagawa, N. Smith and A. Kow ADA, 1999, Characterizing crustal earthquake slip models for the prediction of strong ground motion, Seism. Res. Lett., 70, 59-80.

武村雅之・諸井孝文・八代和彦, 明治以後の内陸浅発地 震の被害から見た強震動の特徵一震度 VII の発生条 件一, 地震 2, 50, 485-505.

谷口仁志, 1998 ,「よみがえる福井震災」全 2 巻, 福井 県.

山中浩明 - 栗田勝実 - 瀬尾和大 - 小嶋啓介 - 佐藤浩章 ・ 宮越 研・赤澤隆士・坂上 実・高橋正義, 1998, 福 井平野における微動アレイ観測と地震観測, 日本地震 学会講演予稿集, A11.

吉岡直人，1974，地震の発生機構と地壳変動及び津波， 東京大学理学系研究科地球物理学専門課程修士論文.

吉川宗治, 1949, 福井地震の震害と地盤, 京都大学防災 研究所研究報告, 第 2 号, 12-20.

若松邦夫 - 野畑有秀, 1998, 福井平野の地下構造と 1948 年福井地震の被害一その 1 微動 H/V の特性と 推定地下構造一, 日本建築学会大会学術講演梗概集, 227-228.

\section{付 録}

不均質断層モデルから生成される強震動

一アスペリティーのみの応力降下を考虑したモデルと 断層面全域での応力降下を考慮したモデルの比較—

SOMERVILLE et al. (1999) により与えられる平均的な 不均質断層モデルは, アスペリティにおけるすべり比

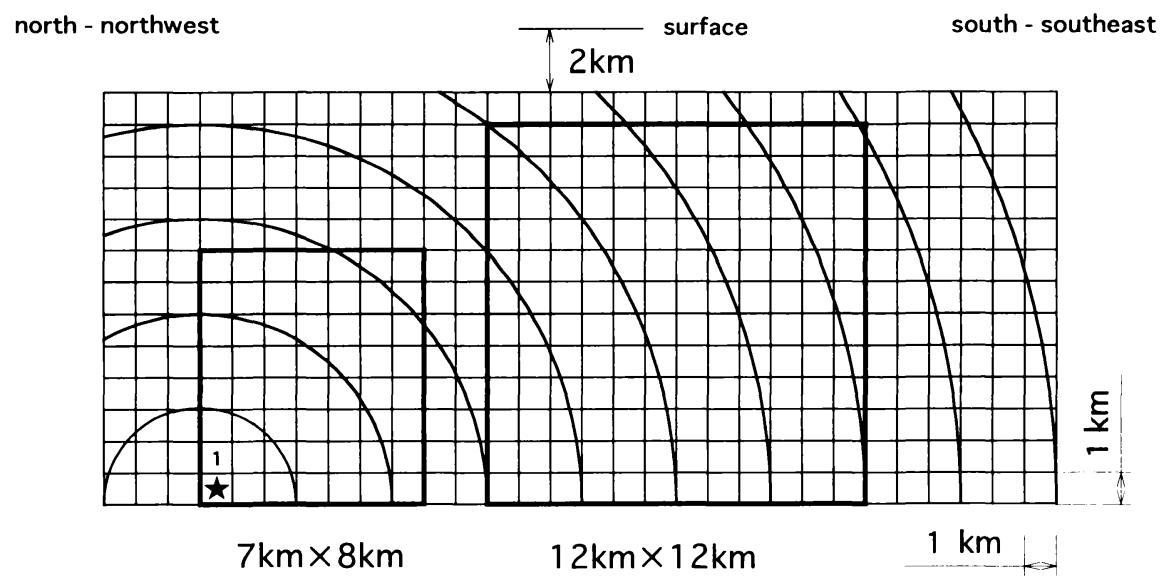

Fig. A1. Asperity source model with background stress drop for simulating the 1948 Fukui earthquake. Two cases are assumed: one is Case 1, non-zero background stress drop and the other Case 2, background stress drop with 19 bars. Both are taken to be the same reverse fault as Model 1 in the text. The areas and stress drops of the two asperities are assumed to be the same as the source model shown Fig. 5. The rupture starts from the left bottom at Asperity No. 1 marked by $\star$ and propagate with constant velocity, $V_{\mathrm{r}}=2.8 \mathrm{~km} / \mathrm{s}$. 


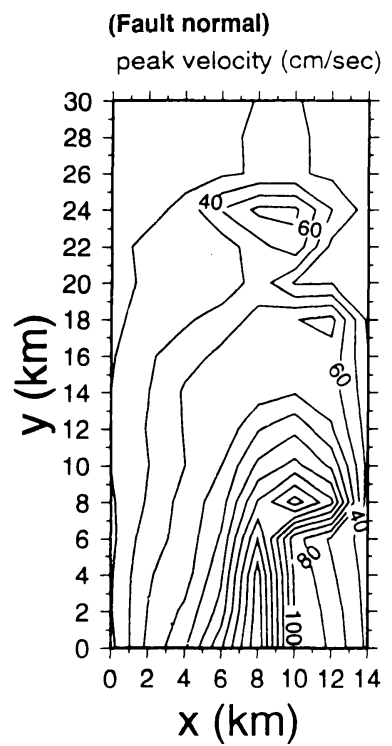

(a)

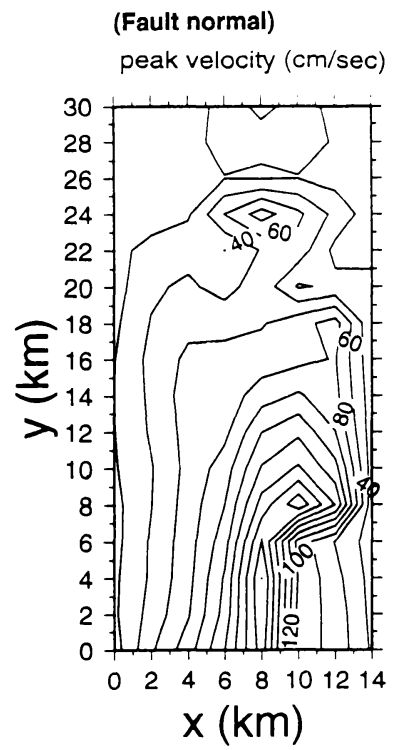

(c)

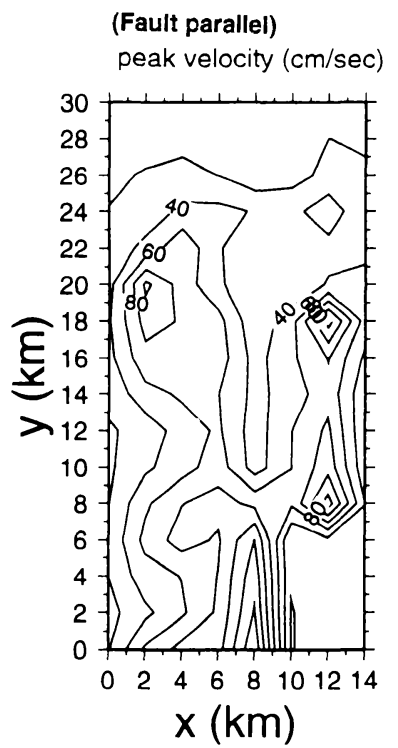

(b)

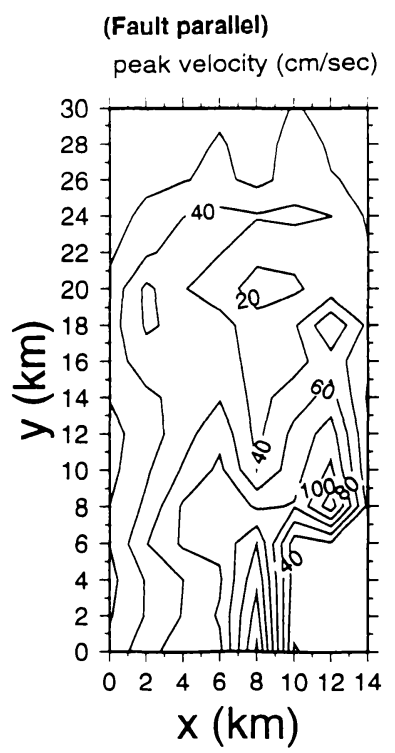

(d)

Fig. A2. Map showing contours of simulated velocity motions for Cases 1 and 2 (Reverse-fault model). (a) and (b) show peak velocity $(\mathrm{cm} / \mathrm{s})$ of fault-normal horizontal-motions and that of fault-parallel horizontal-motions for Case 1. (c) and (d) show peak velocity $(\mathrm{cm} / \mathrm{s})$ of fault-normal horizontalmotions and that of fault-parallel horizontal motions for Case 2.

（全断首面での平均すべり量に対するアスペリティ領域 での平均すべり量の比）が 1.5 3.0 に分布し，その平均 值は約 2 倍である. 全アスペリティの総面積は断層面積 の約 $22 \%$ を占め, よってアスペリティ領域からのモー メント解放量は全体の $44 \%(2 \times 22 \%)$ となる，すなわ
ち, 本研究で採用したアスペリティーのみからなる不均 質断層モデルは，44\%のモーメントの解放しか考慮し ていないことになる。そこで, 震源断層面のアスペリ ティーのみのモーメント解放を想定した場合（ケース 1）とアスペリティー以外でのモーメント解放も想定し 
た場合（ケース2）の強震動を比較する．本論中の計算 はケース 1 に相当する.

想定する震源モデルの全断層面積, 走行, 傾斜角, す ベり角は本文中のモデル 1 と同じとしているが, Fig.

A1 に示されるように破壊の伝播模様が異なる. 破壊の 発震点はアスペリティーNo. 1 の北端の最深点で, 破壊 は一定速度 $2.8 \mathrm{~km} / \mathrm{s}$ で広がるとする. 本文中のモデル ではアスペリティーNo. 1 と No. 2 の破壊の始まりに 7 秒の時間差 [菊地・他 (1999)] を置いたがここでは一様 な破壊伝播を考える. ケース1はアスペリティーNo. 1 と No. 2 でそれぞれ応力降下 186 bars と 113 bars でそ れ以外の領域で応力降下ゼロと仮定する. 一方ヶース 2 はアスペリティーNo. 1 と No. 2 での応力降下量はケー ス 1 と同じで，それ以外の領域での応力降下は 19 bars とする. 結果としてヶース 2 では全断層域からのモー
メントは $2.6 \cdot 10^{19} \mathrm{Nm}$ となる. ケース 1 のトータルな モーメント解放量はケース 2 の約 $4 \%$ 程度である.

ケース 1 に対する強震動の断層直交成分と断層平行 成分の最大速度分布が Fig. A2 の (a) と (b) に示される. ケース 2 に対して同様に断首直交成分と断層平行成分 の最大速度分布が Fig. A2 の (c) と (d) に示される. (a) と (c), (b) と (d)をそれぞれ比較すると両ケースに対する 最大速度分布が詳細にはすこしづつ異なるが傾向がよく 似ていることがわかる. 特に振幅の大きい断首直交成分 はアスペリティーNo. 1 の南端付近で破壊の指向性の影 響で最大速度が大きくなる傾向など振幅分布は極めてよ く似ている.

従って, 不均質断層モデルに対する強震動の最大速度 分布はアスペリティーのみのモーメント解放を仮定して あ近似的には問題ない. 